\title{
Genetic Diversity of Quantitative Traits of Sugarcane Genotypes in Ethiopia
}

\author{
Esayas Tena ${ }^{*}$, Firew Mekbib², Amsalu Ayana ${ }^{3}$ \\ ${ }^{1}$ Sugar Corporation of Ethiopia, Research and Training, Wonji, Ethiopia \\ ${ }^{2}$ School of Plant Sciences, Haramaya University, Haramaya, Ethiopia \\ ${ }^{3}$ Integrated Seed Sector Development Ethiopia Program, Addis Ababa, Ethiopia \\ Email: *esutena11@gmail.com, firew.mekbib@gmail.com, ayana6a@yahoo.com
}

Received 6 March 2016; accepted 26 July 2016; published 29 July 2016

Copyright (C) 2016 by authors and Scientific Research Publishing Inc.

This work is licensed under the Creative Commons Attribution International License (CC BY).

http://creativecommons.org/licenses/by/4.0/

c) (i) Open Access

\begin{abstract}
Information about the amount and distribution of genetic variation in germplasm collections is important for their efficient management and effective utilization in plant breeding. Therefore this study was conducted to assess genetic diversity of sugarcane germplasm in Ethiopia. An experiment comprising of 400 sugarcane genotypes (174 local and 226 introduced) was conducted between March 2012 and October 2013 at Wonji and Metehara Sugar Estates using partial balanced lattice design with two replications. Data was recorded on 21 quantitative characters which included cane yield and its components, sugar yield and sugar quality traits. ANOVA portrayed highly significant differences $(P<0.01)$ among the genotypes for 21 quantitative traits. Cluster analysis revealed intra cluster $D^{2}$ values ranging from $2.16-10.60$ and inter cluster from 7.24 5864. There were six principal components accounting for $79.26 \%$ of the total variation in the tested materials. Millable stalk count, single cane weight, stalk diameter, cane yield, sugar yield and sugar quality traits showed high positive loading on the first two PCs and accounted for most of the variation observed among the genotypes. Therefore, this study suggested that the important characters responsible for diversity in the sugarcane genotypes could be grouped in two principal components namely "Yield" and "Quality" with "Yield" traits being comparatively more important than "Quality". Genotypes clustered for high mean values of various traits could be exploited for further improvement of the crop either through selection or through hybridization. The clusters having high mean value for yield could be selected for yield per se as well.
\end{abstract}

\section{Keywords}

ANOVA, Cluster Analysis, Local and Introduced Sugarcane Genotypes, PCA

\footnotetext{
${ }^{*}$ Corresponding author.
} 


\section{Introduction}

Saccharum is a complex genus characterized by high ploidy levels and composed of at least six distinct species-S. officinarum, S. barberi, S. sinensi, S. spontaneum, S. robustum and S. edule. Accurate assessment of genetic diversity is very important in crop breeding as it helps in the selection of desirable genotypes, identifying diverse parental combination for further improvement through selection in the segregating populations, and introgressing desirable genes from diverse germplasm into the available genetic base. Therefore, genetically diverse germplasm is needed in breeding programs to enhance the productivity and diversity of cultivars. Utilization of introduced germplasm and the knowledge of genetic remoteness among them are vital for their manipulation in crop improvement program [1]. In any breeding program collection of germplasm is always the first step as it provides plant breeders with sources of useful traits. Especially collecting local germplasm would be crucial as they provide locally adapted genes for better crop improvement. Towards this effort, an exploration and collection of local sugarcane germplasm in different geographic regions of Ethiopia has been conducted and more than 300 materials were collected [2]. Documented in a history of the monastery in Northern Ethiopia, it was learnt during this survey that sugarcane had been growing in the country since around $16^{\text {th }}$ century [2]. It is presumed that sugarcane was introduced into Ethiopia in the $16^{\text {th }}$ century by the Portuguese with other food crops like rice, banana, lime, mandarin and ginger [3].

Sugarcane has commercially been grown in Ethiopia for the manufacture of white sugar in the Upper Awash River Basin at Wonji on 5000 ha since 1951 which was started by a Dutch Handles Vereening Ammsterdam (HVA) company [4]. The second sugar estate at Metahara started production in 1969/70 and the third at Fincha in 1998. At present sugarcane is cultivated on 37,000 ha and the four sugar mills in different parts of the country produce about 300,000 ton sugar per annum. Data from the last 10 years (2004-2013) indicated that the average cane yield at Wonj and Metahara ranged from 1300 - 1500 qt/ha and 1700 - 1800 qt/ha, respectively. Similarly, the average sugar percent obtained from the sugar mills indicated $11.5 \%-12.5 \%$ at Wonji and $10 \%-11 \%$ at Metahara. Accordingly the sugar yield ranged from 162.5 - 187.5 qt/ha and 187 - 198 qt/ha at Wonji and Metahara respectively.

As it has never had its own breeding program, the sugar industry of Ethiopia has been relying on imported varieties to satisfy the varietal requirements of the sugar cane plantations. So far more than 300 varieties were imported. Currently only 6 to 7 varieties are grown widely and commercially across Ethiopian Sugar Estates. This is because most of the varieties were not adaptable to the local agro ecological conditions of the country. Even the varieties under cultivation now are of old generations and are contracted with many problems and consequently of low yielders. In light of these, the Sugar Corporation of Ethiopia is currently on its way of establishing sugarcane breeding program. Therefore, establishment of good sources of sugarcane germplasm, of both exotic and local origin, and its characterization are of great importance to provide a diverse genetic base and efficient management of the germplasm source for sugarcane improvement program of Ethioipa.

Information about the amount and distribution of genetic variation in the germplasm collections is important for their efficient management and effective utilization in the breeding program. Multivariate statistical analysis techniques like Principal Component Analysis (PCA) and Cluster Analysis techniques could be used for evaluating genetic diversity among sugarcane genotypes. In studies on genetic divergence using cluster analysis, Mahalanobis' generalized distance $\left(\mathrm{D}^{2}\right)$ is commonly used as a measurement of proximity [5] due to the fact that characteristics with different measurement units and normally correlated are being considered, the optimization method of Tocher is also frequently used as a clustering algorithm, as described by [6].

These analyses have been used successfully to study genetic diversity. Reference [7] studied 30 hybrid clones involving Saccharum barberi, S. officinarum, and co-hybrid to evaluate their seven parents to find out the nature and pattern of genetic divergence. The clones were grouped in 15 clusters and grouping of progeny clones was independent of parent cross combination. They concluded that hybridization among clones from diverse clusters may help in isolating progenies with higher sugar yield and its traits. Reference [8] evaluated sugarcane germplasm from field plots of four Saccharum species and four commercial cultivars by means of analysis of sugar composition. Cluster analysis indicated heterogeneity within and among these species. They concluded that information on sugar composition should assist breeders in selecting superior clones for the relevant breeding programs. Ninety-four genotypes of S. spontaneum were studied by [9] for principal component and cluster analysis based on seven quantitative traits of $S$. spontaneum. The three principal components obtained provided 82.47\% cumulative variance. Based on these seven traits, the 94 S. spontaneum genotypes were grouped into 4 
clusters.

The present study was conducted to quantify the genetic diversity of quantitative traits using multivariate methods for locally collected and introduced germplasm in Ethiopia.

\section{Materials and Methods}

\subsection{Description of the Study Sites and Plant Material}

The experiment was conducted at Wonji and Metehara sugar estates during 2012/2013.

\subsubsection{Wonji}

Wonji Sugar Factory is located in Oromia Regional Government State, Eastern Shewa Zone, Adama Woreda, About $110 \mathrm{~km}$ from Addis Ababa and about $10 \mathrm{~km}$ south of Adama Town with latitude $8^{\circ} 31$ 'N and longitude $39^{\circ} 12^{\prime} \mathrm{E}$ with elevation of 1550 masl. The average annual rainfall is $800 \mathrm{~mm}$ with maximum and minimum temperatures $26.9^{\circ} \mathrm{C}$ and $15.3^{\circ} \mathrm{C}$ respectively [10].

\subsubsection{Metehara}

Metehara sugar factory is located in Oromia Regional Government State, Eastern Shewa Zone about $200 \mathrm{Km}$ from Addis Ababa and about $8 \mathrm{~km}$ south of Metehara Town with latitude and longitude $8^{\circ} 51^{\prime} \mathrm{N}$ and $39^{\circ} 52^{\prime} \mathrm{E}$ respectively and with elevation of 950 masl. Annual rainfall is $554 \mathrm{~mm}$ with temperature maximum and minimum of $32.6^{\circ} \mathrm{C}$ and $17.5^{\circ} \mathrm{C}$ respectively [10].

\subsection{Plant Materials}

The plant materials for this study consisted of a total of 400 accessions of which 174 were local sugarcane germplasm collected from different regional states of Ethiopia and 226 were introduced sugarcane germplasm collections maintained at conservation garden of Research and Training, Sugar Corporation, found at Wonji (see Appendix in Supplementary Material available online at http://dx.doi.org/10.4236/ajps.2016.710139). Selection among the local genotypes was made based on geographical regions where the materials were collected and the morphological variations noted during the collection work and when the varieties were quarantined in their collection areas for one year. In exotic/introduced genotypes selection was made taking into consideration the variation in place of origin i.e. source countries and different periods of introductions to the country.

\subsection{Experimental Design and Field Layout}

The experiment was laid out in $20 \times 20$ partial balanced lattice design with two replications. Canes were cut into three budded sets and planted in single row plots of $5 \mathrm{~m} \times 1.45 \mathrm{~m}$ and $20 \mathrm{~cm}$ between plants within a row. Uniform crop management practices like irrigation, cultivation and fertilization were applied to all entries in the trial as recommended for the areas. Urea was applied 2.5 months after planting at a rate of $200 \mathrm{~kg} \cdot \mathrm{ha}^{-1}$ at Wonji and $400 \mathrm{~kg} \cdot \mathrm{ha}^{-1}$ at Metehara. The crop was harvested 20 months after planting as plant cane takes 18 - 20 months to mature at the two sugar estates.

\subsection{Data Collected}

Data on quantitative stalk characters (Table 1) was recorded viz sprout count 1 and 2 months after planting (SPC1MAP and SPC2MAP), tiller counts 4 and 5 month after planting (TC4MAP and TC5MAP), stalk count 10 months after planting (STC10MAP), hand refractometer brix reading 10 months after planting (HRBrix 10MAP), Millable stalk count per hectare (MSCHA), single cane weight (SCW), number of internode (NOI), internode length (IL), stalk height (SH), stalk diameter (SD), leaf length (LL), leaf width (LW), leaf area (LA), Cane yield per hectare (CYHA), Sugar yield quintal per hectare (SY). Data on juice quality parameters i.e. brix percent (brix\%), pol percent (pol\%), purity percent (purity\%) and sugar percent (SR\%) was also recorded. For every accession, ten plants were used for recording data for quantitative characters, which were recorded on plot basis. Count data and cane yield was recorded considering all cane stalks from the whole plot. For quantitative leaf characteristics measurement, a procedure developed by [12] was used. 
Table 1. List of quantitative characters recorded in the study.

\begin{tabular}{|c|c|c|}
\hline Quantitative Traits & Code & Description \\
\hline Sprout count & SPC & Number of primary/mother shoot emerged from planted bud \\
\hline Tiller count & TC & $\begin{array}{l}\text { Number of secondary, tertiary, etc shoots emerged from } \\
\text { primary shoots }\end{array}$ \\
\hline Leaf length $(\mathrm{cm})$ & LL & Length of the third leaf from the flag leaf \\
\hline Leaf width (cm) & LW & Width of the third leaf from the flag leaf \\
\hline Leaf area $\left(\mathrm{cm}^{2}\right)$ & LA & $\begin{array}{l}\text { Area of the third leaf from the flag leaf, computed as (leaf length } \times \\
\text { leaf width } \times 0.747) \text { suggested by Stickler } \text { et al. }(1961)\end{array}$ \\
\hline Stalk count 10 month after planting & STC10MAP & The number of millable stalks 10 month after planting \\
\hline HRBrix percent 10 month after planting & HRBrix10MAP & Hand rifractometer brix reading 10 month after planting \\
\hline Number of millable canes (count)/plot & MSCPL & stalks with four or more visible internodes at 10 months or after \\
\hline Number of millable canes (count)/hectare & MSCHA & $\begin{array}{l}\text { Number of millable cane produced per hectare calculated from } \\
\text { millable stalk count per plot }\end{array}$ \\
\hline Stalk thickness/diameter (cm) & SD & Width of stalk at mid internode \\
\hline Stalk height/Cane length/ (cm) & $\mathrm{SH}$ & $\begin{array}{l}\text { Height of a sugarcane plant measured from ground level to the } \\
\text { top visible dewelap. }\end{array}$ \\
\hline Number of internodes (count) & $\mathrm{NI}$ & Count of total internodes per plant \\
\hline Internode length (cm) & $\mathrm{IL}$ & Length of the third internode counted from the ground surface \\
\hline Cane yield per plot (Kg) & CYPL & Weight of cane harvested from an experiment plot \\
\hline Cane yield per hectare (qt/ha) & CYHA & $\begin{array}{l}\text { The weight of millable sugarcane produced per hectare of land } \\
\text { or calculated from cane yield per plot }\end{array}$ \\
\hline Single cane weight (kg) & SCW & $\begin{array}{l}\text { Weight of cane harvested from an experiment plot divided by } \\
\text { the number of millable cane per plot }\end{array}$ \\
\hline Brix percent & Brix\% & $\begin{array}{l}\text { Juice Brix refers to the total solids content present in the juice } \\
\text { expressed in percentage. Brix includes sugars as well as } \\
\text { non-sugars as indicated by a brix hydrometer. }\end{array}$ \\
\hline Pol percent/ Juice Sucrose percent & Pol\% & $\begin{array}{l}\text { The juice sucrose per cent is the actual cane sugar present in } \\
\text { the juice determined by reading on the scale of polarimeter. }\end{array}$ \\
\hline Purity percent & Purity\% & The ratio of pol to brix. Pty $=\mathrm{Pol} / \mathrm{Bx} \times 100$ \\
\hline Sugar percent & $\mathrm{SR} \%$ & $\begin{array}{l}\text { Amount of sugar recovered from the cane. Obtained by the formula: } \\
=((\mathrm{pol} \%-(\text { brix } \%-\text { pol\% }) * 0.7)) * 0.75 \text { as described in Winter Carp } \\
\text { indirect method of cane juice analysis }[11] .\end{array}$ \\
\hline Sugar yield per hectare (qt/ha) & SY & $\begin{array}{l}\text { Amount of crystal sugar produced per hectare of land. Obtained } \\
\text { by multiplying cane yield per hectare with sugar percent }\end{array}$ \\
\hline
\end{tabular}

\subsection{Statistical Analysis}

\subsubsection{ANOVA}

All the quantitative agro-morphological characters and sugar juice quality parameters considered (Table 1) in the study were statistically analyzed as simple partial balanced lattice design using the statistical procedures described by [13]. Characters with count data were log transformed before analysis [13]. ANOVA was done first separately for the two locations. Combined ANOVA was done over locations after the homogeneity of error variance was tested using the F-max method of [14], which is based on the ratio of the larger mean square of error (MSE) from the separate analysis of variance to the smaller mean square of error as:

$$
\mathrm{F}-\text { ratio }=\frac{\text { Larger MSE }}{\text { Smaller MSE }}
$$


If the larger error mean square is not three-fold larger than the smaller error mean square, the error variance was considered homogeneous [13].

For characters having significant mean differences, the difference between treatment means was compared using Tukey's Studentized Range (HSD) Test at 5\% of probability. All statistical analyses and data processing was performed using SAS software V9.

\subsubsection{Cluster Analysis}

Cluster analysis was employed by average linkage method using the appropriate procedure of SAS software V9. Means of each quantitative character were standardised prior to clustering as suggested by [15] to avoid the effect due to difference in scale. The genotypes were grouped into different clusters using Tocher's method as described by [16]. The resulting cluster was subjected to Mahalanobis' $\mathrm{D}^{2}$ statistics to assess inter and intra divergence among clusters.

\subsubsection{Principal Component Analysis}

Principal component analysis (PCA) was used as a data reduction tool to summarise the information from phenotypic data so that the influence of noise and outliers on the clustering results is reduced. Principal component analysis was performed on the traits using SAS software V9 in order to study the relationship among the genotypes and to complement and confirm the grouping obtained through cluster analysis [17] [18].

\section{Results and Discussion}

\subsection{Analysis of Variance}

Analysis of variance results for 400 genotypes indicated significant differences for all the characters under study (Table 2). All phenotypic traits including sugar quality traits showed highly significant variation revealing a high level of genetic diversity among them. Therefore, the existence of the genetic variability among the studied clones demonstrated a favorable situation to practice the breeding program. This result indicates that there was significant amount of phenotypic variability and all the genotypes differed with each other with regard to the characters that opened a way to proceed for further improvement through simple selection. Genetic variability in germplasm resources is a prerequisite to practice selection [19] [20]. The relatively large genotypic mean squares indicated that clones differed in their potential for the traits. Significant genotype $\times$ location interactions for most of the traits revealed that mean performances of the genotypes were influenced by the locations. This interaction was largely due to changes in the relative ranking of the genotypes across the locations which suggest that at this stage evaluating sugarcane genotypes in more locations rather than one may be satisfactory.

Comparative advantages of means of characters of the $5 \%$ best selected accessions (Appendix 1 ) for most of the agronomic traits showed that local varieties collected from different geographic regions of the country had superiority over the standard varieties B52298 and NCO334 and mean of commercial cane cultivars (MCV) (Table 3) and those of the introduced varieties amongst the 5\% best selected. Though the sucrose recovery percent was relatively higher for the introduced varieties amongst the best $5 \%$ selected, the higher cane yield per plot recorded for the local varieties compensated for their superior sugar yield over the standard varieties and mean of MCV. The local variety Nech Ageda collected from Amhara Region, Debub Welo Zone, Borena Wereda showed the highest sugar yield and $60.66 \%$, 38.13\% and $127.85 \%$ comparative sugar yield advantage over B52298, NCO334 and MCV respectively.

This variety had the highest stalk count per plot recorded 10 months after planting during which time that is 9 - 10 months after planting when the stalk population stabilizes and the potential number of millable stalk would be known. The highest cane yield was also recorded for this variety.

Relatively higher tiller counts per plot four and five months after planting was recorded for the local varieties Ye Beskula Shenkora, Nech Kechacha Shenkora/Getr, Moris and Engda and among introduced varieties like CO810, CO991, CP72/2083, DB386/60 showed higher tiller counts (Appendix 1). The highest millable stalk count at harvest was recorded for B4425, B45154, CO842, B4906, CO957, Ye Beskula Shenkora, Nech Ageda, Aladi, and Moris. With regard to cane yield among the 5\% best selected (20 clones) 18 were local varieties and only two introduced varieties namely B4425 and N55/805. This was also true in measure of single cane weight where 17 of the 20 selected were local varieties. Relatively higher inter node counts were recorded for the local clones whereas higher inter node length was observed in the introduced varieties. Among the 20 best selected 
Table 2. Analysis of variance for morphological and juice quality traits of sugarcane tested over two locations (Wonji and Metehara 2012/2013).

\begin{tabular}{|c|c|c|c|c|c|c|c|}
\hline Characters $^{\dagger}$ & Location & Replication & block(Replication) & Accession & Location*Accession & Error & CV (\%) \\
\hline & (1) & (1) & (19) & (380) & (399) & (780) & \\
\hline SPC1MAP & $10.675^{* *}$ & $6.887 *$ & $1.102^{\mathrm{ns}}$ & $1.978^{* *}$ & $1.938 * *$ & 1.055 & 49.24 \\
\hline SPC2MAP & $386.921^{* *}$ & $20.108^{* *}$ & $1.240^{\mathrm{ns}}$ & $1.498^{* *}$ & $1.237^{*}$ & 1.044 & 35.89 \\
\hline TC4MAP & $567.169 * *$ & $23.802 * *$ & $0.983^{\text {ns }}$ & $1.875^{* *}$ & $1.237^{* *}$ & 0.957 & 25.27 \\
\hline TC5MAP & $44.092 * *$ & $0.082^{\mathrm{ns}}$ & $0.626^{\text {ns }}$ & $0.953 * *$ & $0.919 * *$ & 0.559 & 18.63 \\
\hline STC10MAP & $46.119 * *$ & $17.248^{* *}$ & $0.372^{\mathrm{ns}}$ & $1.066^{* *}$ & $0.616^{* *}$ & 0.289 & 13.88 \\
\hline HRBrix10MAP & $591.961^{* *}$ & $50.116^{* *}$ & $3.531^{\mathrm{ns}}$ & $3.138^{\mathrm{ns}}$ & $3.430^{\mathrm{ns}}$ & 3.424 & 12.10 \\
\hline MSCHA & $40.712 * *$ & $3.074^{* *}$ & $0.409 *$ & $1.196 * *$ & $0.590^{* *}$ & 0.252 & 4.49 \\
\hline SCW & $1.180^{* *}$ & $3.156^{* *}$ & $0.145^{\mathrm{ns}}$ & $0.517 * *$ & $0.166^{* *}$ & 0.123 & 23.12 \\
\hline NOI & $779.806^{* *}$ & $250.431^{* *}$ & $18.531^{\mathrm{ns}}$ & $52.037 * *$ & $26.659 * *$ & 14.623 & 13.57 \\
\hline IL & $20.473^{\mathrm{ns}}$ & $1.962^{\mathrm{ns}}$ & $7.351^{\mathrm{ns}}$ & $15.618^{* *}$ & $10.229^{\mathrm{ns}}$ & 9.235 & 34.35 \\
\hline SH & $88352.063^{* *}$ & $9279.902 * *$ & $640.917^{\mathrm{ns}}$ & $3337.181^{* *}$ & $1243.085^{* *}$ & 872.007 & 12.29 \\
\hline SD & $5.050^{* *}$ & $0.001^{\mathrm{ns}}$ & $0.042^{\mathrm{ns}}$ & $0.337^{* *}$ & $0.089 * *$ & 0.060 & 9.18 \\
\hline LL & $8953.181^{* *}$ & $5978.962 * *$ & $212.970^{\text {ns }}$ & $526.532 * *$ & $359.608^{* *}$ & 189.594 & 10.76 \\
\hline LW & $0.483^{\text {ns }}$ & $27.152 * *$ & $0.483^{\mathrm{ns}}$ & $1.844^{* *}$ & $0.792 * *$ & 0.622 & 18.39 \\
\hline LA & $132290.602^{* *}$ & $545322.802^{* *}$ & $6137.660^{\mathrm{ns}}$ & $25433.571^{* *}$ & $12832.068^{* *}$ & 9734.180 & 23.89 \\
\hline СYHA & $5857126.000^{* *}$ & $7375569.600^{* *}$ & $284712.100^{\mathrm{ns}}$ & $1667648.400^{* *}$ & $619916.600^{* *}$ & 279325.000 & 39.12 \\
\hline Brix & $4.364^{\mathrm{ns}}$ & $24.310^{* *}$ & $1.271^{\mathrm{ns}}$ & $5.225 * *$ & $2.164 *$ & 1.791 & 6.90 \\
\hline Pol & $34.281^{* *}$ & $32.627 * *$ & $1.499^{\mathrm{ns}}$ & $6.202^{* *}$ & $2.410^{* *}$ & 1.861 & 7.52 \\
\hline Purity & $354.399 * *$ & $19.678^{\mathrm{ns}}$ & $7.269^{\mathrm{ns}}$ & $13.471^{* *}$ & $8.545^{* *}$ & 6.697 & 2.77 \\
\hline SR & $61.297 * *$ & $20.338 * *$ & $1.036^{\mathrm{ns}}$ & $4.052 * *$ & $1.601^{* *}$ & 1.199 & 8.44 \\
\hline SY & $38976.630 * *$ & $79538.100 * *$ & $5466.260^{\text {ns }}$ & $30595.530 * *$ & $11103.880^{* *}$ & 5298.920 & 41.00 \\
\hline
\end{tabular}

${ }^{\dagger}$ SPC1MAP and SPC2MAP = Sprout count 1 and 2 months after planting; TC4MAP and TC5MAP = Tiller counts 4 and 5 month after planting; STC10MAP = Stalk count 10 months after planting; HRBrix10MAP = Hand rifractometer brix reading 10 months after planting; MSCHA = Millable stalk count per hectare; SCW = Single cane weight $(\mathrm{Kg})$; NOI = Number of internode; IL = Internode length $(\mathrm{cm})$; SH = Stalk height $(\mathrm{cm})$; SD = Stalk diameter $(\mathrm{cm})$; LL = Leaf length $(\mathrm{cm}) ; \mathrm{LW}=$ Leaf width $(\mathrm{cm})$ LA = Leaf area $\left(\mathrm{cm}^{2}\right.$; CYHA = Cane yield $(\mathrm{qt} / \mathrm{ha})$; Brix = Brix percent; Pol = Pol percent; Purity = Purity percent; SR = Sugar percent; $\mathrm{SY}=$ Sugar yield (qt/ha); ${ }^{*} P=0.05,{ }^{* * P}<0.01$, ns $=$ non significant, numbers in parenthesis are degrees of freedom.

Table 3. Mean of 21 quantitative characters* for 10 commercial varieties in Ethiopian sugar estates.

\begin{tabular}{cccccccccccccccccccccc}
\hline Accessions & $\mathbf{A}$ & $\mathbf{B}$ & $\mathbf{C}$ & $\mathbf{D}$ & $\mathbf{E}$ & $\mathbf{F}$ & $\mathbf{G}$ & $\mathbf{H}$ & $\mathbf{I}$ & $\mathbf{J}$ & $\mathbf{K}$ & $\mathbf{L}$ & $\mathbf{M}$ & $\mathbf{N}$ & $\mathbf{O}$ & $\mathbf{P}$ & $\mathbf{Q}$ & $\mathbf{R}$ & $\mathbf{S}$ & $\mathbf{T}$ & $\mathbf{U}$ \\
\hline B 41227 & 30 & 126 & 118 & 51 & 33 & 16.00 & 119310 & 1.42 & 28 & 28.00 & 246.70 & 2.30 & 119.00 & 3.30 & 392.26 & 1962.10 & 18.59 & 17.48 & 93.85 & 12.53 & 269.02 \\
B 52298 & 18 & 33 & 70 & 67 & 75 & 15.45 & 122414 & 1.77 & 26 & 7.68 & 197.15 & 2.76 & 147.63 & 4.28 & 470.29 & 2169.25 & 20.23 & 18.80 & 92.92 & 13.40 & 289.75 \\
CO 449 & 9 & 22 & 33 & 55 & 45 & 15.05 & 105172 & 0.98 & 23 & 10.84 & 244.73 & 2.34 & 135.80 & 4.49 & 456.73 & 995.00 & 19.66 & 18.45 & 93.79 & 13.24 & 135.00 \\
CO 678 & 2 & 11 & 49 & 44 & 35 & 16.37 & 41379 & 1.01 & 19 & 9.89 & 192.33 & 2.48 & 135.30 & 4.13 & 413.25 & 475.75 & 16.64 & 14.77 & 88.65 & 10.16 & 51.25 \\
CO 680 & 10 & 22 & 46 & 51 & 46 & 14.76 & 56207 & 2.04 & 31 & 7.91 & 243.35 & 2.65 & 136.55 & 4.72 & 482.91 & 1160.50 & 20.40 & 19.15 & 93.81 & 13.75 & 162.75 \\
CO 740 & 3 & 23 & 42 & 95 & 41 & 15.12 & 74828 & 1.57 & 29 & 8.42 & 235.38 & 2.77 & 110.20 & 4.66 & 385.05 & 1257.75 & 19.73 & 18.17 & 92.12 & 12.86 & 161.25 \\
DB 377/60 & 13 & 32 & 63 & 58 & 59 & 16.50 & 79483 & 1.41 & 30 & 7.82 & 231.89 & 3.04 & 136.38 & 4.36 & 450.66 & 1106.50 & 19.76 & 18.30 & 92.47 & 13.00 & 144.50 \\
Mex 54/245 & 8 & 5 & 40 & 49 & 42 & 14.76 & 95517 & 1.78 & 27 & 10.12 & 256.68 & 2.81 & 123.75 & 5.56 & 518.19 & 1710.50 & 19.96 & 18.59 & 93.05 & 13.24 & 230.00 \\
N 14 & 18 & 25 & 85 & 90 & 76 & 17.26 & 113104 & 1.61 & 29 & 8.69 & 250.40 & 2.53 & 137.10 & 3.76 & 383.62 & 1819.25 & 20.82 & 19.91 & 95.61 & 14.48 & 262.50 \\
NCO 334 & 6 & 37 & 134 & 62 & 109 & 13.51 & 166207 & 1.46 & 27 & 9.06 & 239.75 & 2.83 & 133.75 & 4.98 & 665.12 & 2424.50 & 19.96 & 19.15 & 95.98 & 13.94 & 337.00 \\
Mean & $\mathbf{1 2}$ & $\mathbf{3 3}$ & $\mathbf{6 8}$ & $\mathbf{6 2}$ & $\mathbf{5 6}$ & $\mathbf{1 5 . 4 8}$ & $\mathbf{9 7 3 6 2}$ & $\mathbf{1 . 5 0}$ & $\mathbf{2 7}$ & $\mathbf{1 0 . 8 4}$ & $\mathbf{2 3 3 . 8 3}$ & $\mathbf{2 . 6 5}$ & $\mathbf{1 3 1 . 5 5}$ & $\mathbf{4 . 4 2}$ & $\mathbf{4 6 1 . 8 1}$ & $\mathbf{1 5 0 8 . 1 1}$ & $\mathbf{1 9 . 5 7}$ & $\mathbf{1 8 . 2 7}$ & $\mathbf{9 3 . 2 3}$ & $\mathbf{1 3 . 0 6}$ & $\mathbf{2 0 4 . 3 0}$
\end{tabular}

*A = Sprout count 1 month after planting; B = Sprout count 2 month after planting; $\mathrm{C}=$ Tiller count 4 month after planting; $\mathrm{D}=$ Tiller count 5 month after planting; $\mathrm{E}=$ Millable stalk count 10 month after planting; $\mathrm{F}=$ Hand refractometer brix reading 10 month after planting; $\mathrm{G}=\mathrm{Millable}$ stalk count per hectare at harvest; $\mathrm{H}=$ Single cane weight $(\mathrm{kg}) ; \mathrm{I}=$ Number of internodes; $\mathrm{J}=$ Internode length $(\mathrm{cm}) ; \mathrm{K}=$ Stalk height $(\mathrm{cm}) ; \mathrm{L}=$ Stalk dimeter $(\mathrm{cm}) ; \mathrm{M}=\mathrm{Leaf}$ length $(\mathrm{cm}) ; \mathrm{N}=$ Leaf width $(\mathrm{cm}) ; \mathrm{O}=$ Leaf area $\left(\mathrm{cm}^{2}\right) ; \mathrm{P}=$ Cane yield (qt/ha); Q = Labratory brix\%; R = Pol\%; S = Purity\%; T = Sugar\%; U = Sugar yield (qt/ha). 
(5\%) for stalk diameter 16 were local varieties where medium thick stalk diameters ranging from 3 - 3.5 [21] was recorded. The highest and lowest stalk diameter was recorded for the local varieties Kay Sidancho and Nech Ye Abesha Shenkora respectively. In terms of leaf area the standard variety NCO334 scored the highest value followed by the local varieties Ye Kenya Ageda and Nech Shenkora (code 35 as in Appendix 1). Among the best $5 \%$ selected, higher values of brix $\%$, pol\%, purity $\%$ and sugar\% were recorded mostly for the introduced varieties.

This information helps to determine the genetic variability and contribution of some morphological traits in cane yield and sucrose recovery and can largely facilitate the formulation of appropriate selection strategies to develop the clones of best commercial merits, which are suitable for the cultivation in different climate zones.

\subsection{Cluster Analysis}

Cluster (segmentation) analysis for phenotypic traits showed a clear demarcation between sugarcane accessions (Table 4). Furthermore, Table 5 showed differences among clusters by summarizing cluster means for the 21 quantitative traits. Based on these traits, the accessions were grouped into different clusters. The dendrogram divided the accessions into nineteen main clusters and a singleton. The first cluster included 136 genotypes out of which 62 were introduced while the rest 74 were local clones. This indicated that these local genotypes have close similarity with the group of exotic sugarcane accessions belonging to this group. This cluster is characterized by accessions having HRBrix10MAP, number of internodes, leaf length values close to the grand mean. Furthermore, it has brix, pol, purity and sugar percent greater than the grand mean averaged over all clusters. Cluster two consisted of 120 accessions where 67 were introduced and 53 local accessions. The genotypes in this cluster demonstrated values greater than the grand mean for most of the traits which included millable stalk number, cane yield, single cane weight, stalk height, stalk diameter, leaf area, brix, pol, purity and sugar present and sugar yield. Genotypes in this cluster could contribute in the future breeding program with regard to these traits. Cluster three had only six local accessions out of the total 80, which were collected from different geographic regions of the country. This indicated that these accessions had genetic similarity with the rest of exotic accessions within the cluster. TC5MAP, STC10MAP, HRBrix10MAP, MSCHA, SH, brix\%, pol\%, purity\% and $\mathrm{SR} \%$ had values greater than the grand mean in this cluster.

Cluster four comprised seventeen accessions all of which were local accessions. This accessions, though collected from different geographic regions of the country, they tend to cluster together indicating source of origin is not the criteria for clustering. Amazingly these genotypes had 18 of the 23 quantitative traits with means greater than the grand mean averaged over all the 20 clusters. Out of these traits TC5MAP, SCW, SH, SD, LL, CYHA and SY had the second largest means from all the clusters. These genotypes reliably would be major contributors to improve these traits in the crossing programs. Cluster five consisted of seven accessions four of which were foreign varieties namely CP 1/441, M112/34, M377/5, Mex53/142 introduced from three source countries i.e. Canal Point, Mauritius and Mexico, respectively. The other three accessions America, Nech Shenkora /Shenkora Adi and Nech Shenkora were local collections from three different regions in the country SNNP, Oromia and Amhara. This cluster had accessions with stalk height, stalk diameter, leaf width, brix, pol, purity, and sugar percent which had values greater than the grand mean and a mean leaf area comparable to the grand mean. Cluster six had eight genotypes all locals except one exotic accession CO945 form Coimbatore, India. This variety should have close similarity with the local accessions with which it cluster together. Accessions in this cluster had mean values greater than the grand mean for number of internode, stalk diameter, leaf length and width and leaf area. Other traits had means lower than the grand mean. Cluster seven contained four exotic accessions B45154 and B58230 from Barbados and CO842 and CO957 from Coimbatore, India. These varieties might share same parents in their genealogical history; this could be the reason for their clustering together. The genotypes in this cluster showed mean performance greater than the grand mean for tiller counts 4 and 5 months after planting, stalk count 10 month after planting, millable stalk number, cane yield, internode length, stalk height and leaf length. However, they had low single cane weight. Furthermore, they had lower means than the grand mean for all sugar quality parameters.

Cluster eight consisted of five local accessions collected from different parts of the country. No exotic variety has clustered with these clones. These accessions demonstrated the shortest internode length, shortest stalk height, the narrowest stalk diameter, lowest single cane weight, narrowest leaf width and the lowest leaf area of all the clusters. They have also showed lower mean than the grand mean for all the traits including sugar quality 
Table 4. Clustering of 400 sugarcane genotypes into twenty clusters using mean of 21 quantitative characters (numbers refer to code of genotypes (see Appendix in Supplementary Material available online at http://dx.doi.org/10.4236/ajps.2016.710139).

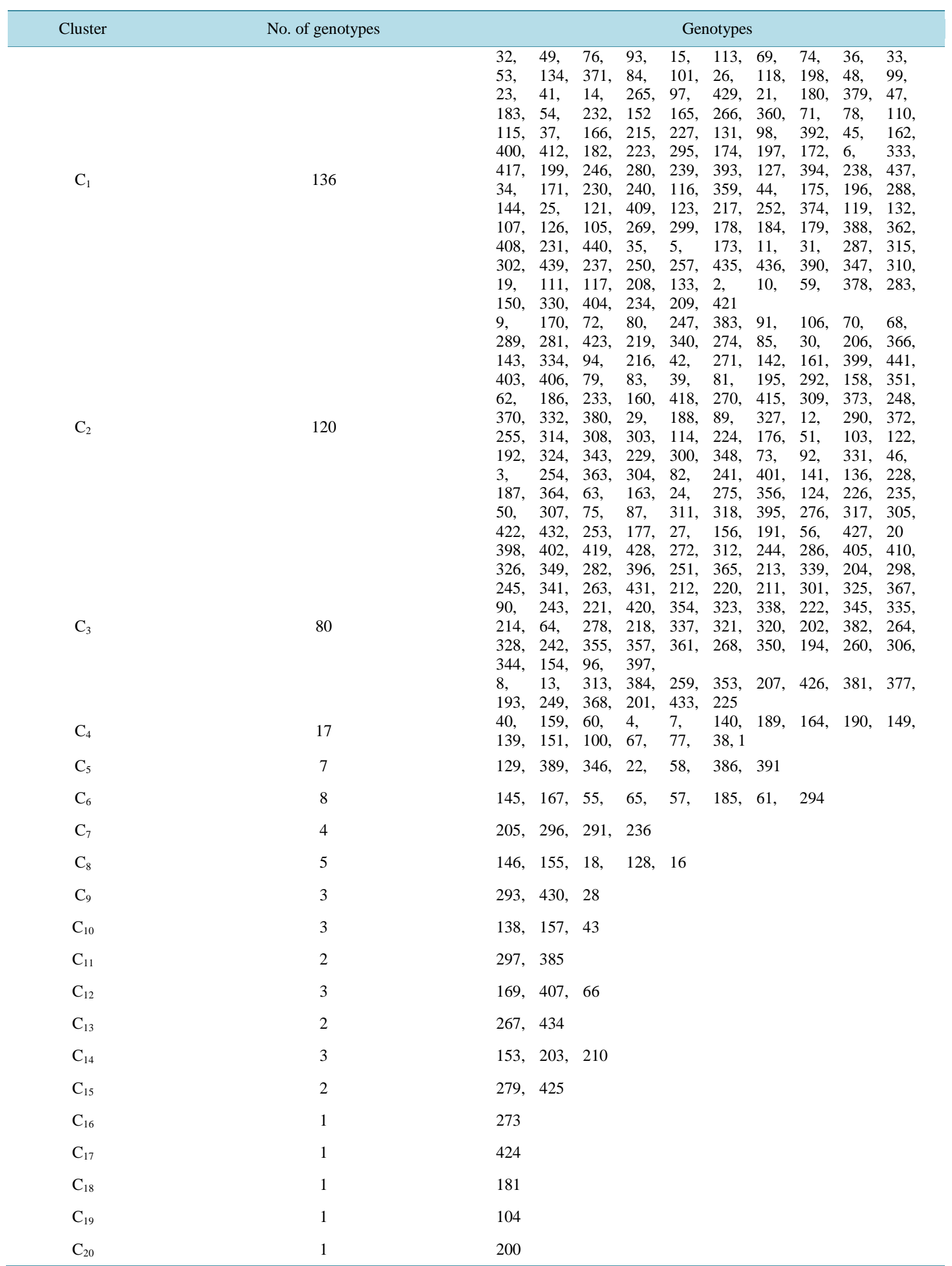




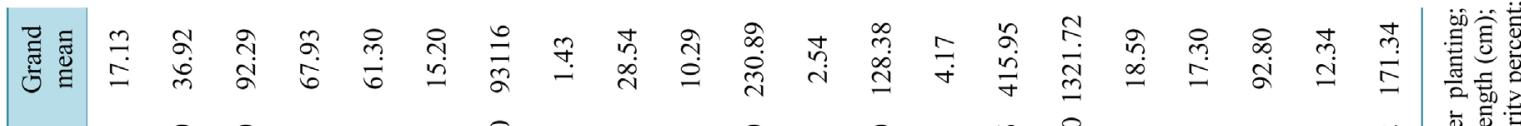

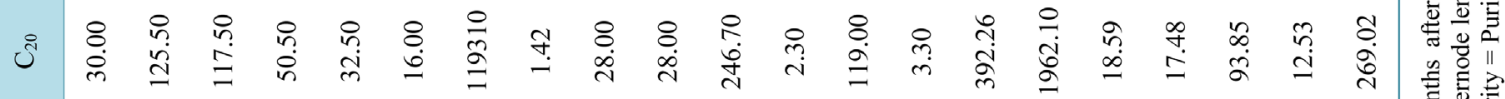

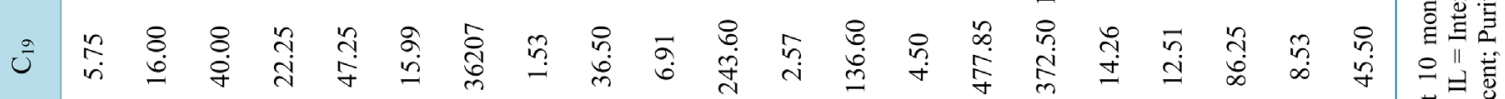
年

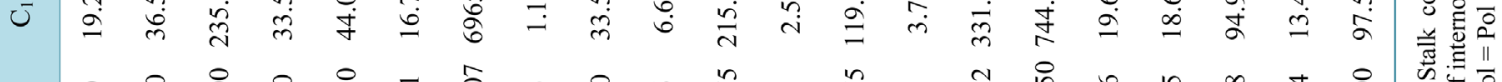

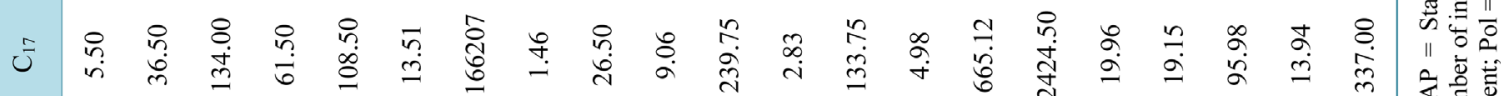

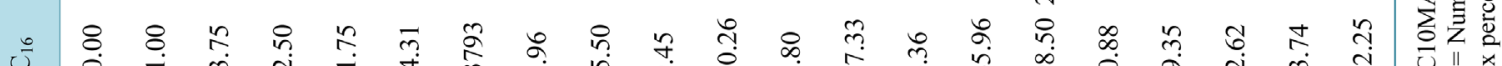

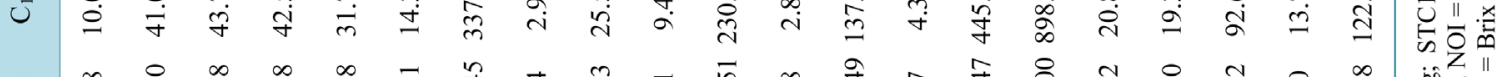

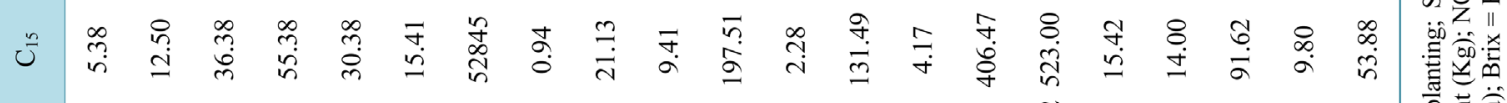

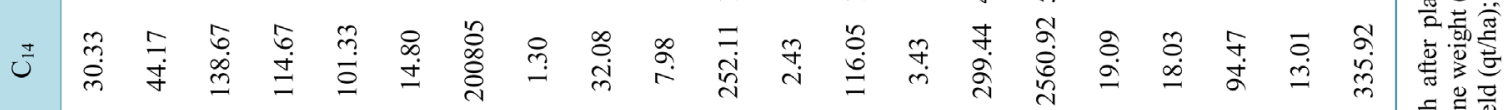

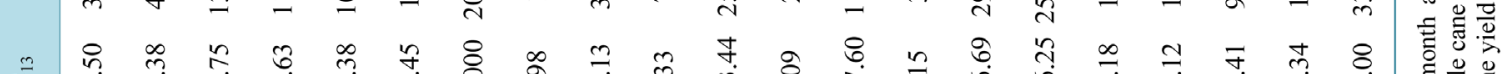

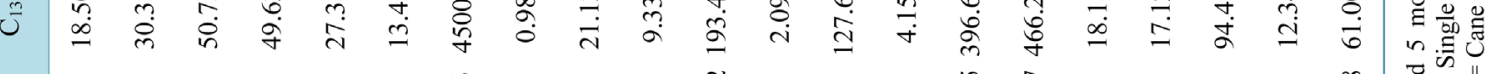

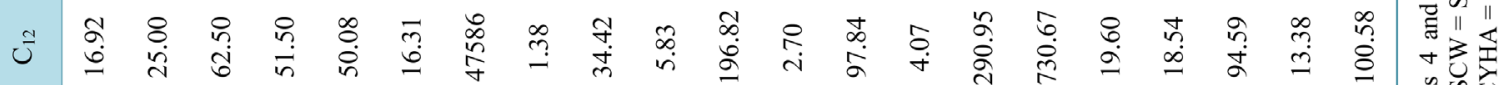

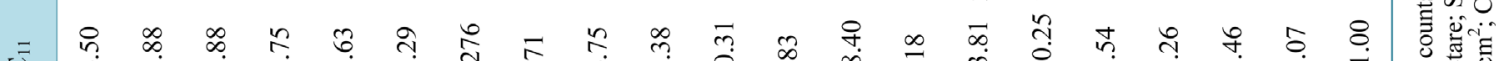

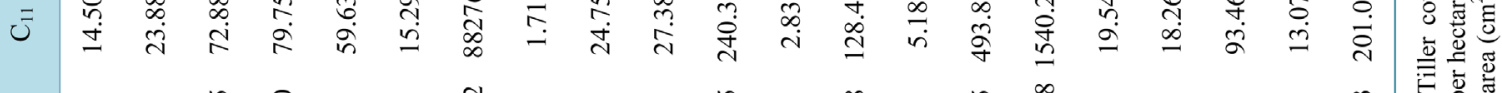

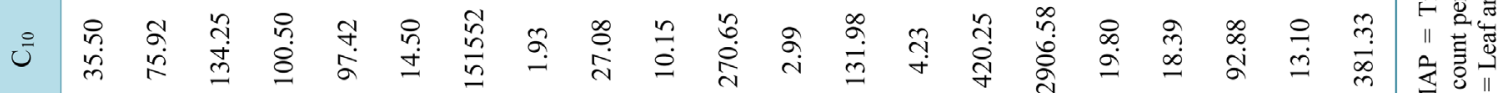

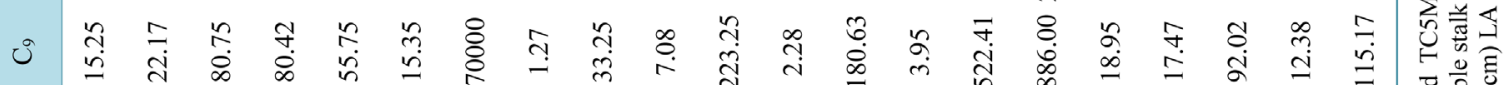

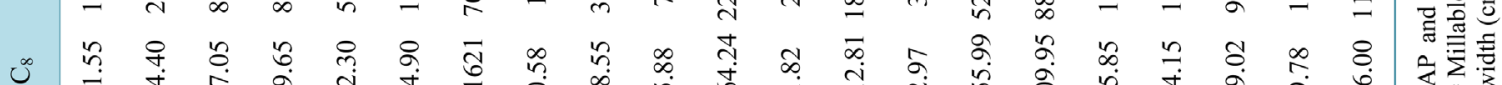

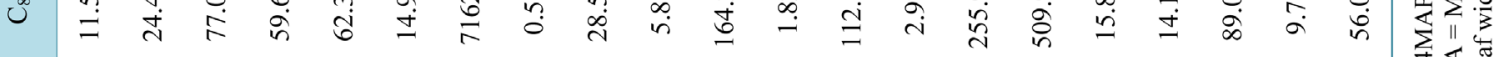

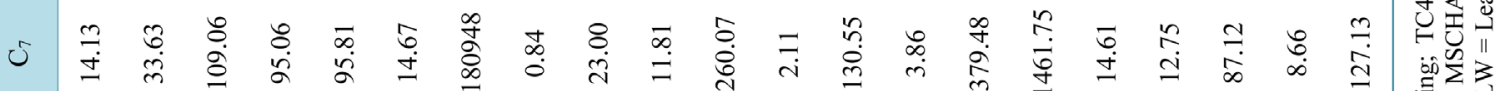

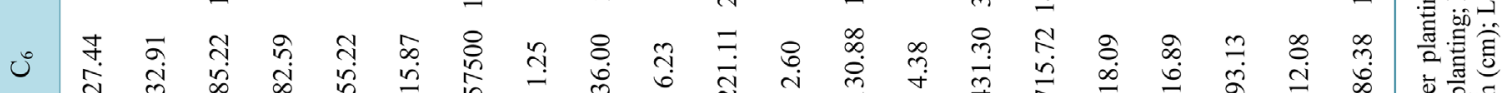

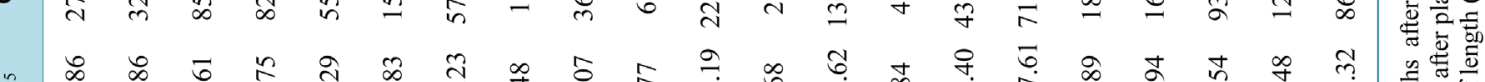

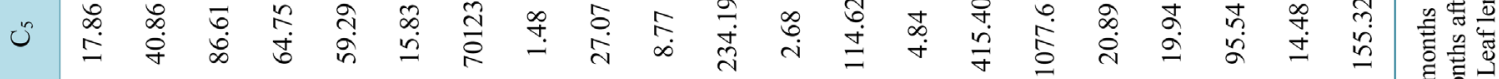
- $\infty$ \&

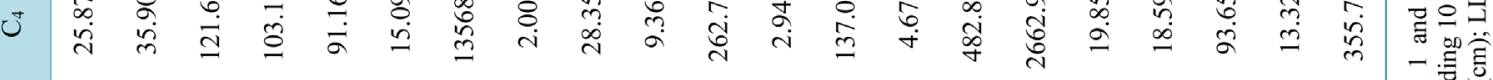

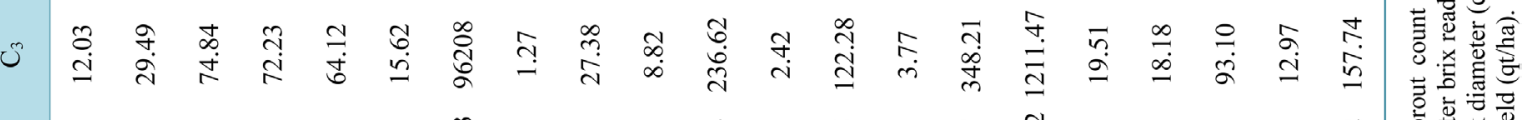

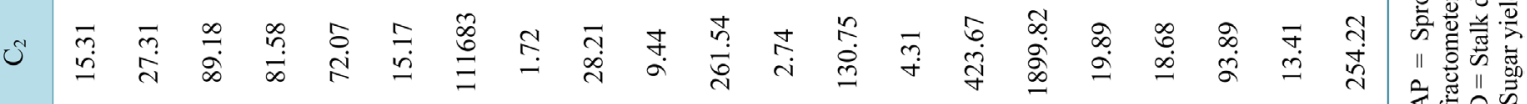

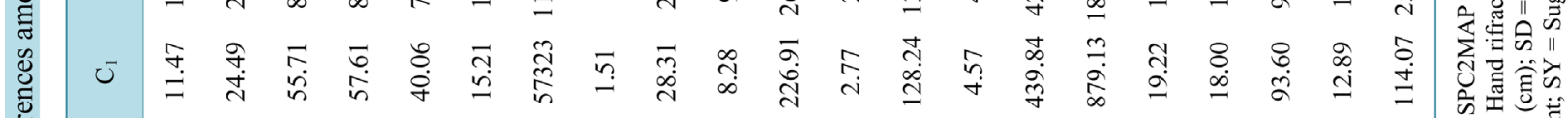
尝

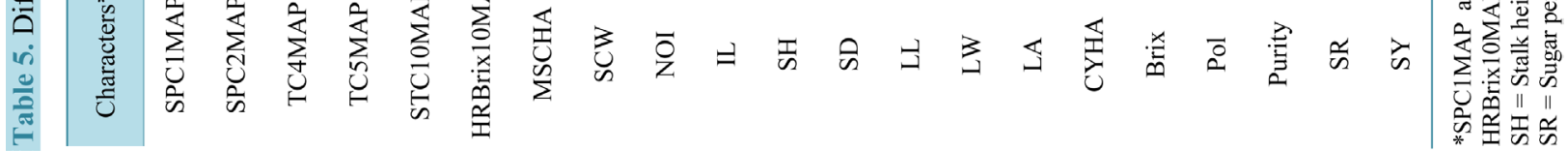


parameters. In terms of sugar yield they out performed only accessions in cluster 15 and 19. These lower means caused the separate clustering of these clones alienated from the exotic varieties and other local clones. They must have also peculiar characters different from those of the introduced varieties and the remaining locals, which required further study. Results from further studies could reveal important traits, which could make them good candidates for future sugarcane breeding program of the country to develop improved varieties that fit to the different agro ecologies of the country. Cluster nine consisted of two foreign clones CO911 and PR980 form Coimbatore, India and Puertorico respectively and one local clone, Nech Shenkora collected from SNNP Region, Amaro special Wereda/Jijola kebele/Kore village/Cheffa district. This local clone should have similar character with the exotic genotypes. It might also be similar to one of these exotic genotypes as there is a possibility for sugarcane germplasm taken from the germplasm conservation gardens found at Wonji and Metehara sugar estates and transported by local seasonal labourers who mostly come from SNNP. The accessions in this cluster had the tallest leaf length and had the highest leaf area next to NCO334 in cluster 17, which is the standard commercial variety. They have also exhibited larger means than the grand mean for number of internode and stalk diameter and for sugar quality characters brix and pol. Cluster ten included three local varieties namely Moris, Kay Ageda and Kay Shenkora collected from SNNP, Semen Mierab Tigray and Debub Tigray respectively. These local clones are suspected that it could be the same variety called with different names in different places, as there is human mediated movement of genotypes. This cluster grouped the accessions with the highest sprout count one month after planting, longest stalk height, the widest stalk diameter, the highest cane yield and highest sugar yield. The mean performance of other characters was also higher than the grand mean. These groups of accessions will be very important to improve the most important yield components and cane and sugar yield in the future breeding program. They could also be selected as candidate varieties to be further evaluated and released for commercial purpose.

Cluster eleven consisted of two introduced genotypes CO961 and M53/263 from Coimbatore, India and Mauritius. The accessions in this cluster were observed having the widest leaf width, the second longest internode length next to accessions in cluster 20, the third widest stalk diameter next to accessions in cluster 10 and 4 and the third largest leaf area next to clones in cluster 17 and 9. These two accessions also had mean values of cane yield, single cane weight, stalk height, sugar yield and all sugar quality characters greater than the grand mean. Cluster twelve comprised of one exotic accession TDRJAN from Australia and two local accessions Nech Ageda collected from Amhara Region, North Shewa Zone, Kewet Wereda and Guracha Shenkora collected from Oromia Region East Hararghe Zone Babile Wereda. Shortest internode and leaf lengths characterize accessions in this cluster. However, they had number of internode and all sugar quality characters greater than the grand mean while other characters had lower values than the grand mean. Cluster thirteen consisted of two foreign clones CO434 and PR1059 introduced from Coimbatore, India and Puertorico respectively. Two other clones from the same countries were also clustered together in cluster 9. This might indicate that some clones in Coimbatore and Puertorico could have same parentage in their genealogy history. These accessions showed lower values than the grand mean for all the characters evaluated. They have also scored the second lowest cane yield.

Cluster fourteen included two accessions from Barbados B4425 and B4906 and one local collection Ye Beskula Shenkora collected from Amhara Region South Welo Zone Legambo Wereda. The grouping of the two Barbados varieties with this local clone revealed that there are shared characteristics among them. The accessions in this group were characterized by the highest number of tiller number 5 month after planting, the highest number of stalk number 10 month after planting, the largest number of millable stalk count and the lowest number of internode. These accessions also gave the third largest cane yield next to accessions in cluster 10 and 4 . The fourth highest sugar yield was also recorded for these group of accessions next to those in cluster 10, 4 and 17. They have also demonstrated higher mean values than the grand mean for most of the other traits. In the future breeding program of the country this group of accession could contribute a lot to improve traits such as tillering ability, millable stalk number and cane yield.

Cluster fifteen had two foreign clones CO678 from Coimbatore, India and 93-V1 from Natal, South Africa. These accessions exhibited the lowest sprout counts 1 and 2 months after planting, the lowest number of tillers 4 month after planting. They had also the third lowest single cane weight after those accessions in cluster 8 and 7 , the lowest number of internode similar to accessions in cluster 13, the fourth lowest stalk height. In terms of sugar quality characters, they showed the third lowest brix, pol and sugar percent next to accessions in clusters 19, 7 and the second lowest sugar yield next to the local clone Burabure Shenkora in cluster 19. Furthermore, for 
the remaining characters their performance was below the grand mean. In the remaining clusters 16 - 20, the accessions were not included in any of the clusters, and grouped as a singleton and stood individually as a separate cluster, this indicates that they were phenotypically dissimilar from the other accessions.

Cluster sixteen had the single accession CO475 introduced from Coimbatore, India. This variety showed the lowest millable stalk number, the highest single cane weight, the second longest leaf length next to accessions in cluster 9, the second highest brix and pol next to accessions in cluster 5 and the third highest sugar percent next to accessions in cluster 5 and 17. This accession had also mean values greater than the grand mean for sprout count 2 month after planting, stalk diameter, leaf width and leaf area. However, for other characters lower mean values than the grand mean was recorded. The accession demonstrated good values for sugar quality characters that could be harnessed for breeding programs. Cluster seventeen consisted of only one accession, the standard commercial variety NCO334, which was introduced from Natal, South Africa. This variety had the largest stalk count 10 month after planting and the highest leaf area. It was also observed that it had the third largest millable stalk number next to accessions in cluster 14 and 7, the fourth highest cane yield, the third widest stalk diameter and the second widest leaf width next to accessions in cluster 11. From sugar quality parameters the third highest brix and pol percents next those in cluster 5 and 16, the second highest sugar percent next to accessions in cluster 5 and the third highest sugar yield next to clones in cluster 10 and 4 was recorded. These values for the observed characters must have caused it to stand as a single cluster.

Cluster eighteen consisted of a single local accession, Gende Lega collected from Oromia Region West Hararghe Zone Gubakoricha Wereda 05 Kebele Nanofaro district. This accession was characterized by having the highest tiller count 4 month after planting. However, this tiller number was seen greatly reduced when counted 5 months after planting. The highest hand rifractometer brix reading 10 month after planting was also recorded for this clone. The highest values recorded for these traits might be the reason for this accession clustering as singleton. For sugar quality parameters higher mean values than the grand means was recorded. Other traits showed lower performance than the grand mean when averaged over all accessions in different clusters. Cluster nineteen had the single local accession, Burabure Shenkora, collected from Benshangul-Gumz region Asosa Zone Megele 32 Sefera Tabia. This local clone is the one found in many parts of the country during the collection period. This local clone was characterized by showing the lowest tiller count 5 month after planting, the lowest cane yield, the lowest brix, pol, purity and sugar percent and the lowest sugar yield per hectare. It had also the second lowest mean values for sprout counts 1 and 2 months after planting, tiller count 4 months after planting and millable stalk number. Higher mean values than the grand mean was recorded only for single cane weight, stalk diameter, stalk height, leaf length and width and leaf area.

The lowest mean values recorded for the important characters mentioned above should be responsible for the clone to stood alone as single cluster. However, this local variety is known for its tolerance to biotic and abiotic stresses and the ability to grow in marginal and drought prone areas. Therefore, it could be exploited for these traits in the future breeding program.

The last grouping, cluster twenty consisted of a single exotic accession B41227. This accession showed the highest sprout counts 2 months after planting and the longest internode length. It has mean values greater than the grand mean for most of the characters including sugar quality parameters and sugar yield. The highest values for sprout count and internode length seemed the reason for it clustering as a singleton.

Though cluster analyses grouped genotypes with greater similarity for agronomic traits, they did not necessarily include the genotypes from the same source or origin. In most of the germplasm resources lack of association between agronomic traits and origin has been reported [22] [23]. This information will be helpful to use in crop breeding through identification of parents.

As discussed above based on the cluster means for different characters as given in Table 5, important characters that differentiate each cluster were identified. Crosses involving parents from these genetically divergent clusters are expected to manifest maximum hetrosis and generate wide variability in genetic architecture. These are also likely to produce potential recombinants with desired traits [24]. The characters contributing maximum to the divergence should be given more emphasis for the purpose of further selection and choice of parents for hybridization. There was high genetic diversity for the quantitative characters in the populations studied. The genetic distances as measured by the pairwise generalized $\mathrm{D}^{2}$ statistics between each cluster is shown in Table 6 . The standardized Mahalanobis $\mathrm{D}^{2}$ statistics showed existence of high genetic distances among clusters. The first exceptionally divergent $\mathrm{D}^{2}$ values were obtained between cluster 20 and the rest of the clusters with $\mathrm{D}^{2}$ values ranging from 480 - 5864. The second exceptionally divergent $D^{2}$ values were between cluster 11 and the remaining 


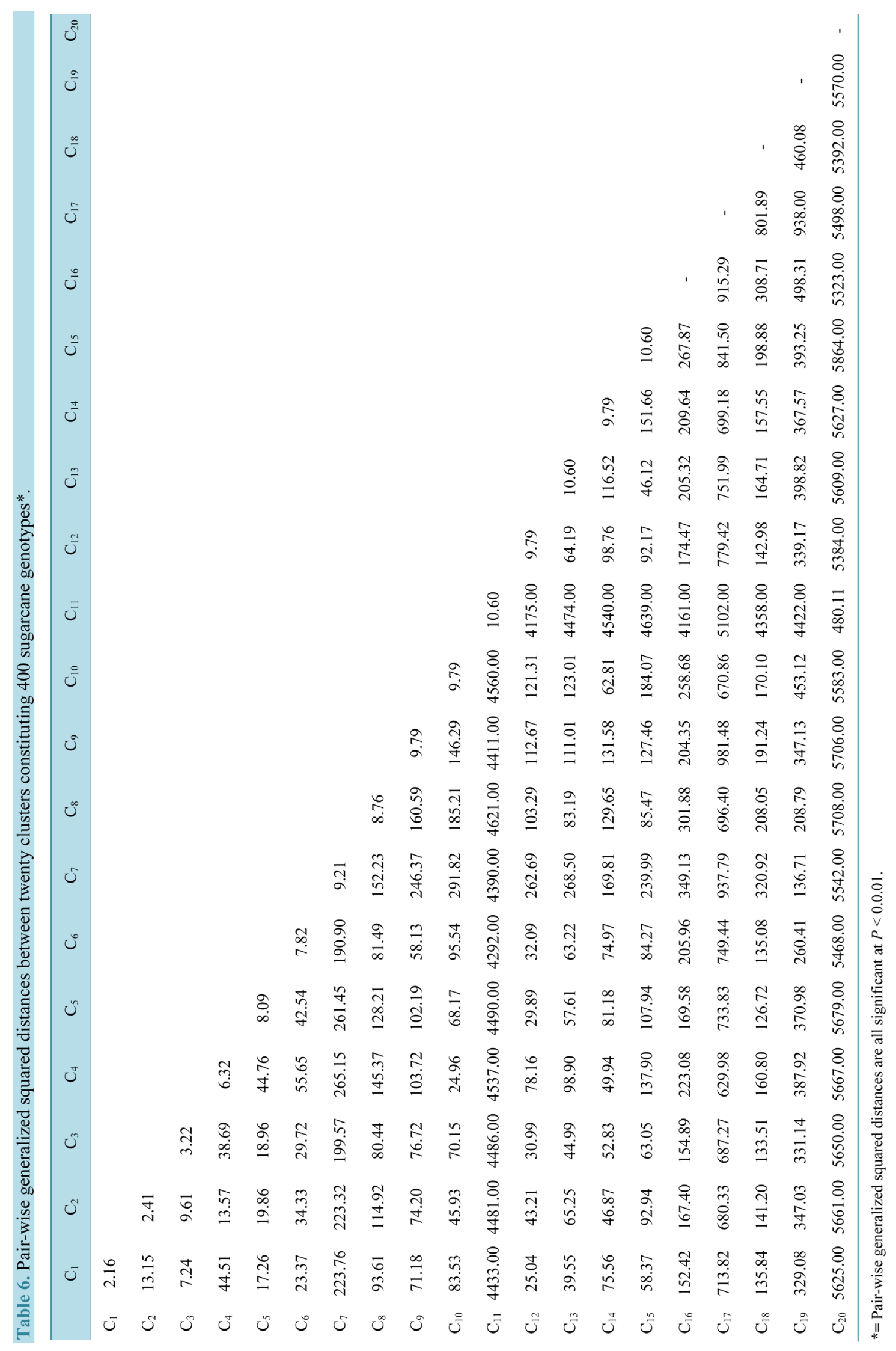


clusters with $\mathrm{D}^{2}$ values ranging from 480 - 5102. The uniquely high distance values in this case may stem from the presence of highly contrasting character references, which resulted in $\mathrm{D}^{2}$ values disproportionately high among the clusters. The maximum genetic distance was found between clusters C15 and C20 with $\mathrm{D}^{2}=5864$. The second most divergent clusters were C8 and C20 with $\mathrm{D}^{2}=5708$ and the third were C9 and C20 with $\mathrm{D}^{2}=$ 5706.

The fourth and fifth most divergent clusters were C5 and C20 with $\mathrm{D}^{2}=5679$ and C4 and C20 with $\mathrm{D}^{2}=5667$, respectively. The highest intra-cluster average $\mathrm{D}^{2}$ value (10.60) was of cluster number 11,13 and 15 while the lowest intra-cluster average $\mathrm{D}^{2}$ value (2.16) was of cluster number 1 (Table 6).

Generally the results of cluster and the $\mathrm{D}^{2}$ analysis have shown that, local genotypes from the same collection site were often in different clusters and likewise accessions from different collection sites often clustered together (Table 4 and Table 6), indicating the possibility of exchange of materials between sites and regions within Ethiopia. Similarly, regardless of their origin foreign sugarcane cultivars from different countries tend to cluster together and likewise accessions from the same foreign country were often in different clusters. Local and exotic genotypes also grouped together in many clusters, which showed there should be some similarity among them. The same phenomenon was reported in sugarcane elsewhere [25] [26] and in sorghum by [27]. This suggests that the genotypes of different locations have genetic similarity and could have been derived from the same breeding material. Similar results were obtained by [7] wherein they found that the progenies of a cross clustered independently of their parents. However, in three of the clusters C4, C6 and C8 except only one foreign clone CO945 in C6, these clusters contained local materials. These local clones should have their own unique properties that separate them from the exotic accessions and the other local clones.

Based on the average intra and inter-cluster distances one can early predict the genetic diversity that exist within and between clusters. Since in Ethiopia little information is available on sugarcane, it could be used for further planning of experiments using huge genetic resources. This information helps to determine the genetic variability and contribution of some morphological traits in cane yield and sucrose recovery and could largely facilitate the formulation of appropriate selection strategies to develop the clones of best commercial merits, which are suitable for the cultivation in different climate zones. [28]-[30] derived information on genetic variability, heritability and genetic advance in sugarcane to develop selection strategies. Genetic divergence investigated in germplasm material would be helpful for selection of important yield influencing characters [31]-[33].

\subsection{Principal Component Analysis}

In the present study the PCA grouped the 21 phenotypic characters into 21 components, which accounted for the entire (100\%) variability among the studied accessions (Table 7). As [34] stated, components with an eigenvalue of less than 1 should be eliminated so that fewer components are dealt with. Furthermore, [35] suggested that eigenvalues greater than one are considered significant and component loadings greater than \pm 0.3 were considered to be meaningful. Hence, from this study, only the first six components which had eigenvalues greater than one and cumulatively explained about $79.26 \%$ of the total variation among the accessions was discussed (Table 7).

The first principal component (PC) alone explained 32.39\% of the total variation, mainly due to variation in the millable stalk count, cane yield, sugar yield and stalk count 10 month after planting. Characters which contributed more to the second PC accounted for $16.06 \%$ of the total variation and were dominated by traits such as single cane weight, stalk diameter, leaf width, leaf area, brix, pol, purity and sugar percent.

The third PC with $12.96 \%$ of the variation was composed of leaf length, leaf width, leaf area, brix\%, pol\% and sugar\%. Leaf area showed the most variation among the characters in this PC with a high positive loading. The fourth PC with $7.80 \%$ of variance comprised sprout count one month and two months after planting, number of internode and internode length. Number of internode contributed much for the variation in this PC with high positive loading.

The eigenvectors of PC5 showed large positive loadings for the sprout count two months after planting followed by inter node length. High negative loading of number of internode was observed for this PC. Leaf length and leaf area contributed much for the $4.69 \%$ variation explained by PC6.

Single cane weight showed high negative loading for this PC. The existence of wider phenotypic diversity among sugarcane accessions studied was further explained by the PCA biplot (Figure 1). 
Table 7. Principal component analysis of 21 quantitative characters in 400 sugarcane genotypes showing eigenvectors, eigenvalues, individual and cumulative percentage of variation explained by the first six PC axes.

\begin{tabular}{|c|c|c|c|c|c|c|}
\hline \multirow{2}{*}{ Characters* } & \multicolumn{5}{|c|}{ Eigenvectors } & \multirow[b]{2}{*}{ PC6 } \\
\hline & PC1 & PC2 & РС3 & PC4 & PC5 & \\
\hline SPC1MAP & 0.16 & -0.07 & 0.05 & 0.47 & 0.34 & 0.11 \\
\hline SPC2MAP & 0.11 & -0.09 & 0.01 & 0.31 & 0.63 & -0.04 \\
\hline TC4MAP & 0.25 & -0.14 & -0.04 & 0.21 & -0.01 & 0.22 \\
\hline TC5MAP & 0.24 & -0.14 & -0.01 & 0.10 & -0.06 & 0.29 \\
\hline STC10MAP & 0.30 & -0.20 & -0.04 & 0.05 & -0.08 & 0.13 \\
\hline HRBrix10MAP & -0.04 & 0.00 & -0.21 & 0.10 & 0.26 & -0.05 \\
\hline MSCHA & 0.32 & -0.20 & -0.03 & -0.11 & -0.10 & 0.05 \\
\hline SCW & 0.16 & 0.30 & 0.23 & 0.10 & -0.02 & -0.37 \\
\hline NOI & -0.03 & 0.03 & -0.09 & 0.56 & -0.35 & -0.14 \\
\hline $\mathrm{IL}$ & 0.14 & -0.01 & 0.12 & -0.42 & 0.48 & -0.12 \\
\hline $\mathrm{SH}$ & 0.25 & 0.05 & 0.07 & -0.13 & -0.02 & -0.31 \\
\hline SD & 0.07 & 0.35 & 0.22 & 0.21 & -0.04 & -0.25 \\
\hline LL & 0.05 & 0.11 & 0.30 & -0.06 & -0.06 & 0.51 \\
\hline LW & 0.00 & 0.29 & 0.37 & 0.04 & 0.04 & 0.14 \\
\hline LA & 0.03 & 0.27 & 0.43 & 0.00 & 0.02 & 0.33 \\
\hline CYHA & 0.35 & -0.01 & 0.09 & -0.02 & -0.09 & -0.14 \\
\hline Brix & 0.15 & 0.33 & -0.31 & -0.10 & 0.03 & 0.09 \\
\hline Pol & 0.15 & 0.35 & -0.33 & -0.07 & 0.03 & 0.11 \\
\hline Purity & 0.08 & 0.29 & -0.27 & 0.08 & 0.04 & 0.14 \\
\hline SR & 0.14 & 0.36 & -0.34 & -0.04 & 0.03 & 0.12 \\
\hline SY & 0.35 & 0.03 & 0.04 & -0.02 & -0.08 & -0.11 \\
\hline Eigen value & 7.45 & 3.69 & 2.98 & 1.79 & 1.23 & 1.08 \\
\hline Individual\% & 32.39 & 16.06 & 12.96 & 7.80 & 5.36 & 4.69 \\
\hline Cumulative\% & 32.39 & 48.44 & 61.40 & 69.20 & 74.57 & 79.26 \\
\hline
\end{tabular}

*SPC1MAP and SPC2MAP = Sprout count 1 and 2 months after planting; TC4MAP and TC5MAP = Tiller counts 4 and 5 month after planting; STC10MAP = Stalk count 10 months after planting; HRBrix10MAP = Hand rifractometer brix reading 10 months after planting; MSCHA = Millable stalk count per hectare; SCW = Single cane weight $(\mathrm{Kg})$; NOI = Number of internode; IL = Internode length $(\mathrm{cm})$; $\mathrm{SH}=\mathrm{Stalk}$ height $(\mathrm{cm})$; SD = Stalk diameter $(\mathrm{cm})$; LL = Leaf length $(\mathrm{cm}) ; \mathrm{LW}=$ Leaf width $(\mathrm{cm})$ LA = Leaf area $\left(\mathrm{cm}^{2} ;\right.$ CYHA = Cane yield $(\mathrm{qt} /$ ha $)$; Brix = Brix percent; Pol = Pol percent; Purity = Purity percent; SR = Sugar percent; SY = Sugar yield (qt/ha)

The PCA biplots provide an overview of the similarities and differences between the quantitative traits of the different accessions and of the interrelationships between the measured variables. The biplot demarcated the accessions with characteristics most explained by the first two dimensions.

The first and the second PCs explained the most variation among the accessions, revealing a high degree of association among the characters studied. Millable stalk count, single cane weight, stalk diameter, cane yield, sugar yield and sugar quality parameters brix\%, pol\%, and sugar\% showed high positive loading on these two PCs. Based on the characters loading on the principal components they could be named as "Yield", and "Quality", components. [36] found 4 principal components giving rise to $76 \%$ variation in the data, with the first component comprising juice quality, yield and stalk diameter traits. [37] also found two principal components 


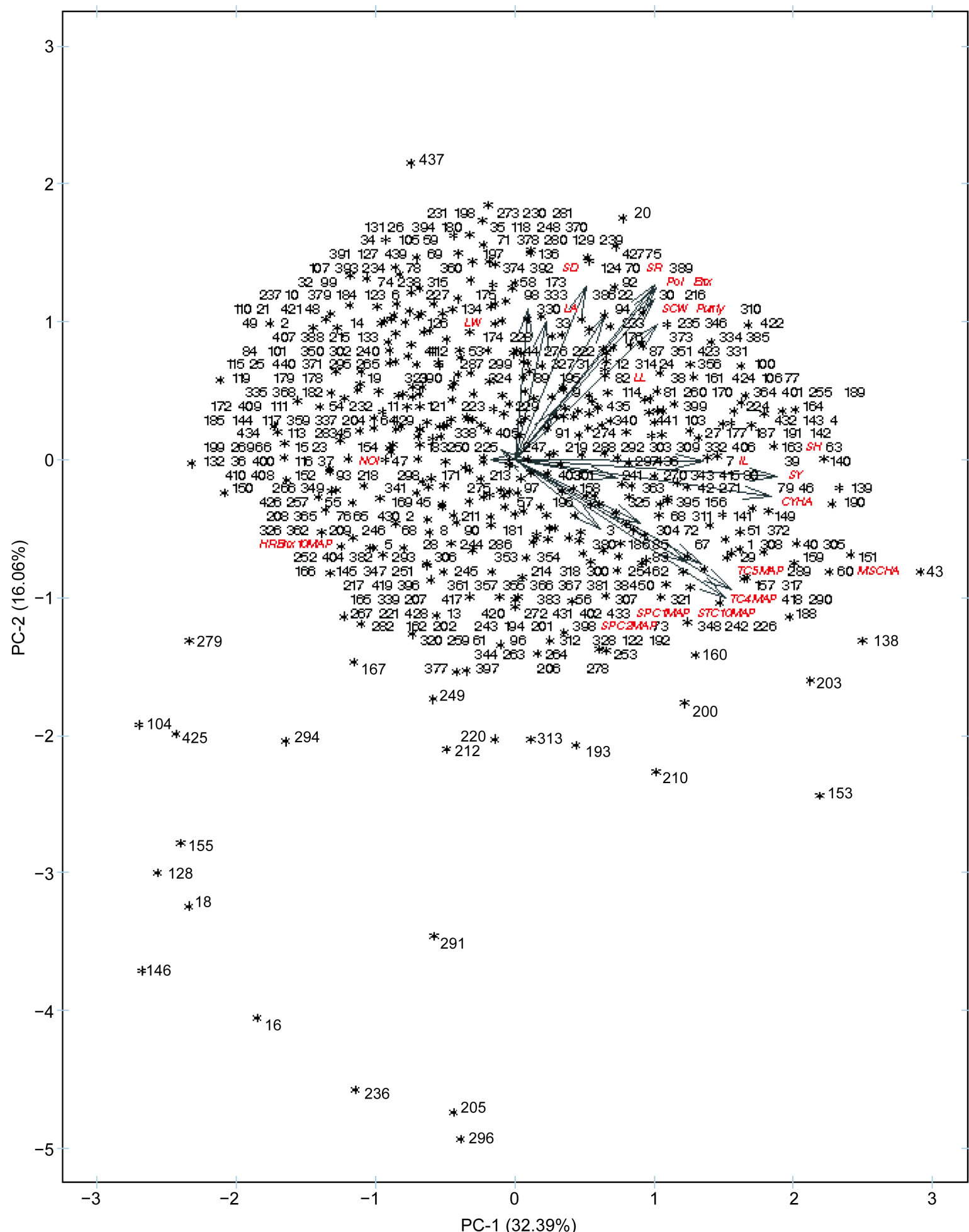

SPC1MAP and SPC2MAP = Sprout count 1 and 2 months after planting;TC4MAP and TC5MAP $=$ Tiller counts 4 and 5 month after planting; STC10MAP = Stalk count 10 months after planting; HRBrix10MAP = Hand rifractometer brix reading 10 months after planting; MSCHA = Millable stalk count per hectare; SCW = Single cane weight $(\mathrm{Kg})$; NOI = Number of internode; IL = Internode length $(\mathrm{cm}) ; \mathrm{SH}=$ Stalk height $(\mathrm{cm})$; SD = Stalk diameter $(\mathrm{cm}) ; \mathrm{LL}=$ Leaf length $(\mathrm{cm}) ; \mathrm{LW}=$ Leaf width $(\mathrm{cm})$ LA = Leaf area $\left(\mathrm{cm}^{2}\right.$; CYHA = Cane yield (qt/ha); Brix = brix percent; Pol = pol percent; Purity = purity percent; SR = Sugar percent; SY = Sugar yield (qt/ha).

Figure 1. Genotype by trait (GT) biplot of 400 sugarcane genotypes in Ethiopia. Genotypes are denoted by code number of genotypes (see Appendix in Supplementary Material available online at http://dx.doi.org/10.4236/ajps.2016.710139). 
explaining $88 \%$ of the variation with high loading of yield on Component 1 and quality characters like sugar recovery, pol\%, and purity\% loading well on Component 2.

With studies conducted on the same genotypes, results showed that, the characters responsible for the high variation in the first two PCs in the present study were also shown to have higher heritability and genetic advance which made them suitable criteria for simple selection [38]. The same report also indicated these characters showed significant genotypic correlations.

\section{Conclusion}

All quantitative phenotypic traits including sugar quality traits showed highly significant variation, revealing a high level of genetic diversity among them that opened a way to proceed for further improvement through simple selection. This study suggests that the important characters responsible for diversity in the sugarcane genotypes could be grouped in two principal components, namely "Yield" and "Quality" with "Yield" traits being comparatively more important than "Quality". Similarly, the 400 genotypes clustered for high mean values of various traits could be exploited for improvement in yield and quality characteristics either through selection or through hybridization. The cluster having high mean values for yield could be selected for yield per se as well.

\section{Acknowledgements}

The authors are grateful to the financial grant of the Sugar Corporation of Ethiopia. Many thanks are forwarded to Ethiopian Biodiversity Institute (EBI) for its technical advice during collection of the local sugarcane genotypes. The staff and laboratory technicians at Wonji and Metehara, Sugar Corporation, Research and Training are duly acknowledged for their supports.

\section{References}

[1] Malik, S.R, Bakhsh, A., Asif, M.A., Iqbal, U. and Iqbal, S.M. (2010) Assessment of Genetic Variability and Interrelationship among some Agronomic Traits in Chickpea. International Journal of Agriculture and Biology, 12, 81-85.

[2] Esayas, T. (2014) Exploration and Collection, Characterization, Genetic Diversity Analysis and Association of Traits for Yield and Yield Components of Sugarcane (Saccharum spp.) in Ethiopia. Ph.D. Dissertation, Haramaya University, Dire Dawa.

[3] Harlan, J.R. (1969) Ethiopia: A Center of Diversity. Economic Botany, 23, 309-314. http://dx.doi.org/10.1007/BF02860676

[4] Mukerji and Associates PLC (2000) Rehabilitation Optimization and Expansion of Agriculture and Factory. Interim Report, Volume I. Sugar Rehabilitation and Expansion, Addis Ababa.

[5] Arunachalam, V. (1981) Genetic Distance in Plant Breeding. Indian Journal of Genetics and Plant Breeding, 41, 226-236.

[6] Singh, R.K. and Chaudhry, B.D. (1979) Biometrical Methods in Quantitative Genetic Analysis. Kalyani Publishers, Ludhiana.

[7] Ram, B. and Hemaprabha, G. (1998) Nature and Pattern of Genetic Divergence of Sugar Yield and its Components in the Progenies of Saccharum barberi. Indian Journal of Gentics and Plant Breeding, 58, 193-199.

[8] Tai, P.Y.P. and Miller, J.D. (2002) Germplasm Diversity among Four Sugarcane Species for Sugar Composition. Crop Science, 4, 958-964. http://dx.doi.org/10.2135/cropsci2002.0958

[9] Zhang, G., Yang, R., Liu, H. and Fang, W. (2006) Principal Component Analysis for 7 Quantitative Traits and Cluster Analysis Based on 7 Quantitative Traits of Saccharum spontaneum L. Southwest China Journal of Agricultural Science, 19, 1127-1131.

[10] ESDA (Ethiopian Sugar Development Agency) (2009) Performance Report. Proceedings of Ethiopian Sugar Industry Biennial Conference, Vol. 1, 186-197.

[11] James, C.P.C. and Chou, C.C. (1993) Cane Sugar Handbook: A Manual for Cane Sugar Manufacturers and Their Chemists. 12th Edition, John Wiley and Sons, Inc., New York.

[12] Stickler, F.C., Weaden, S. and Pauli, A.W. (1961) Leaf Area Determination in Grain Sorghum. Journal of Agriculture, 53, 187-188.

[13] Gomez, K.I. and Gomez, A.A. (1984) Statistical Procedure for Agricultural Research. John Willey and Sons, New York. 
[14] Hartley, H.O. (1950) The Maximum F-Ratio as a Short Cut Test for Heterogeneity of Variances. Biometrika, 37:308-312. http://dx.doi.org/10.2307/2332383

[15] Ruiz, M., Varela, F. and Carillo, J.M. (1997) Analysis of the Discriminating Power of Agro Morphological and Biochemical Descriptors in a Sample of Spanish Collection Barely (Hordeum vulgare L.). Genetic Resource and Crop Evolution, 44, 247-255. http://dx.doi.org/10.1023/A:1008688424315

[16] Rao, C.R. (1952) Advanced Statistical Methods in Biometrics Research. John Willey and Sons, New York.

[17] Afifi, A.A. and Clark, V. (1990) Computer-aided Multivariate Analysis. 2nd Edition, Van Nostrand Reinhold Comp., New York

[18] Crossa, J., DeLacy, I.H. and Taba, S. (1995) The Use of Multivariate Methods in Developing a Core Collection. In: Hodgkin, T., Brown, A.H.D., J.L., T.H. and Morales, E.A.V., Eds., Core Collections of Plant Genetic Resources, International Plant Genetic Resource Institute (IPIGRI), Rome, 77-92.

[19] Punia, M.S. (1982) Studies on Variability, Heritability and Genetic Advance of Some Quality Attributes in Sugarcane. Indian Sugar, 31, 911-914.

[20] Khan, I.A., Khatari, A., Siddiqui, M.A., Nizamani, G.S. and Raza, S. (2004) Performance of Promising Sugarcane Clones for Yield and Quality in Different Ecological Zones of Sindhi. Pakistan Journal of Botany, 36, 83-92.

[21] Nosheen, N.E. and Ashraf, M. (2001) A Comparative Study of the Morphological Characters of Six Sugarcane Varieties. Department of Biological Science, Azan University of Islamabad, Pakistan, 48-54.

[22] Ghafoor, A., Ahmad, Z. and Anwar, R. (2005) Genetic Diversity in Pisum sativum and a Strategy for Indigenous Biodiversity Conservation. Pakistan Journal of Botany, 37, 71-77.

[23] Perera, M., Arias, M., Costilla, D., Luque, A., García, M., Romero, C., et al. (2012) Genetic Diversity Assessment and Genotype Identification in Sugarcane Based on DNA Markers and Morphological Traits. Euphytica, 185, 491-514. http://dx.doi.org/10.1007/s10681-012-0661-9

[24] Singh, V. and Singh, F. (1989) Genetic Diversity and Stability in Chickpea. Indian Journal of Genetics, 49, 349-353.

[25] Mariotti, J.A., Chavanne, E.R., and Cuenya, M.I. (1990) Estimation of Number of Effective Factors ("Loci”) which Determine the Genotype Variability of Brix in Sugarcane (Saccharum spp.). Sugarcane, 3, 7-11.

[26] Phillip, J. (2010) Use and Improvement of Sugarcane Germplasm. CSIRO Plant Industry, ACIAR, Canberra.

[27] Arunkumar, B. and Biradar, B.D. (2004) Genetic Divergence Studies in Rabi Sorghum. Karnataka Journal of Agricultural Science, 17, 571-573.

[28] Singh, A.P., Chatterjee, A. and Nema, G.K. (1996) Genetic Variability in Sugarcane (Sacchrum spp. Complex.). Crop Research (Hisar), 12, 162-164.

[29] Das, P.K., Nayak, B.C., Nayak, N. and Parida, A.K. (1996) Genetic Variability in Biometrical Traits of Early Maturing Genotypes of Sugarcane. Indian Sugar, 46, 723-726.

[30] Kumar, S. and Ram, B. (1996) Genetic Variability, Heritability and Correlations in Hybrid x Species Progenies of Sugarcane Grown Under Saline Conditions. Sugarcane, 2, 17-19.

[31] Doule, R.B. and Balasundaram, N. (1997) Variability, Heritability and Genetic Advance for Yield and Quality Attributes in Sugarcane. Indian Sugar, 47, 499-502.

[32] Kadian, S.P., Chander, K. and Sabharwal, P.S. (1997) Genetic Variability and Heritability in Sugarcane. Indian Sugar, 46, 973-975.

[33] Verma, S.K. and Sachan, J.N. (2000) Genetic Divergence in Indain Mustard (B. juncea (L) Czern and Coss). Crop Research (Hisar), 19, 271-276.

[34] Chatfield, C. and Collin, A.J. (1980) Introduction to Multivariate Analysis. Chapman and Hall, Methuen, Inc., New York. http://dx.doi.org/10.1007/s10681-012-0661-9

[35] Hair, J.F., Andrson, J.R., Tatham, R.E., Black, W.C. (1998) Multivariate Data Analysis. 5th Edition, Prentice-Hall International Inc., London.

[36] Muyco, R.R. (2000) Genetic Diversity in Sugarcane (Saccharum spp. L.) from the Active Germplasm Collection of PHILSURIN (Philippine Sugar Research Inst.) Based on Coefficient of Parentage, Agro-morphological Traits and DNA Microsatellite Markers. http://agris.fao.org/agris-search/search.do?recordID=PH2003001327

[37] Mohammad, T., Hidayatur, R., Rahmani, G., Amjad, A. and Muhammad, K. (2013) Genetic Divergence in Sugarcane Genotypes. American Journal of Experimental Agriculture, 3, 102-109. http://dx.doi.org/10.1007/s10681-012-0661-9

[38] Esayas, T., Firew, M. and Amsalu, A. (2016) Heritability and Correlation among Sugarcane (Saccharum spp.) Yield and Some Agronomic and Sugar Quality Traits in Ethiopia. American Journal of Plant Science, 7, 1453-1477. 


\section{Appendix}

Appendix 1. Comparison of mean performances of $5 \%$ of the genotypes selected for best agronomic and sugar quality performance with standard commercial varieties of B52298, NCO334 and with mean performances of commercial varieties (MCV).

\begin{tabular}{|c|c|c|c|c|c|c|c|c|c|c|c|c|c|c|c|c|c|}
\hline \multirow[t]{2}{*}{ Code } & \multirow[t]{2}{*}{ Accessions } & \multirow[t]{2}{*}{ Mean } & \multicolumn{3}{|c|}{$\begin{array}{l}\text { Comparative } \\
\text { advantage } \\
\text { (\% over) }\end{array}$} & \multirow[t]{2}{*}{ Code } & \multirow[t]{2}{*}{ Accessions } & \multirow[t]{2}{*}{ Mean } & \multicolumn{3}{|c|}{$\begin{array}{l}\text { Comparative } \\
\text { advantage } \\
\text { (\% over) }\end{array}$} & \multirow[t]{2}{*}{ Code } & \multirow[t]{2}{*}{ Accessions } & \multirow[t]{2}{*}{ Mean } & \multicolumn{3}{|c|}{$\begin{array}{c}\text { Comparative } \\
\text { advantage } \\
\text { (\% over) }\end{array}$} \\
\hline & & & $\begin{array}{c}\text { B } \\
52298\end{array}$ & $\begin{array}{c}\text { NCO } \\
334\end{array}$ & $\mathrm{MCV}$ & & & & $\begin{array}{c}\text { B } \\
52298\end{array}$ & $\begin{array}{c}\text { NCO } \\
334\end{array}$ & MCV & & & & $\begin{array}{c}\text { B } \\
52298\end{array}$ & $\begin{array}{c}\text { NCO } \\
334\end{array}$ & MCV \\
\hline \multicolumn{2}{|c|}{ TC4MAP } & & & & & \multicolumn{2}{|c|}{ TC5MAP } & \multicolumn{10}{|c|}{ STC10MAP } \\
\hline 181 & Gende Lega & 235 & 236.92 & 75.37 & 245.59 & 290 & CO 810 & 142 & 113.53 & 130.89 & 129.03 & 151 & $\begin{array}{l}\text { Nech } \\
\text { Ageda }\end{array}$ & 124 & 65.77 & 13.82 & 121.03 \\
\hline 1 & $\begin{array}{c}\text { Nech } \\
\text { Shenkora }\end{array}$ & 191 & 174.19 & 42.72 & 181.25 & 153 & $\begin{array}{l}\text { Ye Beskula } \\
\text { Shenkora }\end{array}$ & 141 & 112.03 & 129.27 & 127.42 & 296 & CO 957 & 120 & 60.74 & 10.37 & 114.32 \\
\hline 190 & Engda & 177 & 153.41 & 31.90 & 159.93 & 67 & $\begin{array}{c}\text { Nech } \\
\text { Kechacha } \\
\text { Shenkora/ } \\
\text { Getr }\end{array}$ & 139 & 108.27 & 125.20 & 123.39 & 153 & $\begin{array}{c}\text { Ye } \\
\text { Beskula } \\
\text { Shenkora }\end{array}$ & 120 & 60.40 & 10.14 & 113.87 \\
\hline 153 & $\begin{array}{l}\text { Ye Beskula } \\
\text { Shenkora }\end{array}$ & 164 & 135.48 & 22.57 & 141.54 & 56 & Wotete & 133 & 100.00 & 116.26 & 114.52 & 188 & Aladi & 112 & 50.67 & 3.46 & 100.89 \\
\hline 138 & $\begin{array}{c}\text { Kay } \\
\text { Ageda }\end{array}$ & 156 & 124.01 & 16.60 & 129.78 & 300 & CO 991 & 131 & 97.37 & 113.41 & 111.69 & 1 & $\begin{array}{c}\text { Nech } \\
\text { Shenkora }\end{array}$ & 111 & 48.99 & 2.30 & 98.66 \\
\hline 67 & $\begin{array}{c}\text { Nech } \\
\text { Kechacha } \\
\text { Shenkora/ } \\
\text { Getr }\end{array}$ & 154 & 120.79 & 14.93 & 126.47 & 60 & Moris & 126 & 89.10 & 104.47 & 102.82 & 40 & $\begin{array}{l}\text { Atena } \\
\text { Moris }\end{array}$ & 110 & 47.32 & 1.15 & 96.42 \\
\hline 159 & $\begin{array}{l}\text { Nech } \\
\text { Shenkora }\end{array}$ & 148 & 111.83 & 10.26 & 117.28 & 348 & CP72/2083 & 125 & 88.35 & 103.66 & 102.02 & 226 & В 53163 & 110 & 47.32 & 1.15 & 96.42 \\
\hline 57 & $\begin{array}{l}\text { Shenkora } \\
\text { Dima/Kay } \\
\text { Shenkora }\end{array}$ & 146 & 109.68 & 9.14 & 115.07 & 190 & Engda & 125 & 87.59 & 102.85 & 101.21 & 424 & NCO 334 & 109 & 45.64 & 0.00 & 94.18 \\
\hline 60 & Moris & 144 & 106.09 & 7.28 & 111.40 & 361 & DB 386/60 & 123 & 84.59 & 99.59 & 97.98 & 43 & Moris & 106 & 41.95 & -2.53 & 89.26 \\
\hline 305 & CO 1157 & 142 & 103.58 & 5.97 & 108.82 & 51 & Wotet & 119 & 78.57 & 93.09 & 91.53 & 348 & CP72/2083 & 105 & 40.27 & -3.69 & 87.02 \\
\hline 290 & CO 810 & 140 & 100.36 & 4.29 & 105.51 & 83 & $\begin{array}{l}\text { Shembeko } \\
\text { Ageda }\end{array}$ & 117 & 75.94 & 90.24 & 88.71 & 203 & B 4425 & 104 & 38.93 & -4.61 & 85.23 \\
\hline 43 & Moris & 137 & 95.70 & 1.87 & 100.74 & 353 & COS 510 & 116 & 74.81 & 89.02 & 87.50 & 138 & $\begin{array}{c}\text { Kay } \\
\text { Ageda }\end{array}$ & 102 & 37.25 & -5.76 & 83.00 \\
\hline 424 & NCO 334 & 134 & 92.11 & 0.00 & 97.06 & 100 & $\begin{array}{c}\text { Nech } \\
\text { Shenkora }\end{array}$ & 116 & 74.44 & 88.62 & 87.10 & 29 & $\begin{array}{c}\text { Andegna } \\
\text { dereja } \\
\text { Wonji }\end{array}$ & 101 & 35.91 & -6.68 & 81.21 \\
\hline 164 & $\begin{array}{l}\text { Yemilat } \\
\text { Nech } \\
\text { Shenkora }\end{array}$ & 132 & 89.25 & -1.49 & 94.12 & 321 & СР44/101 & 116 & 74.06 & 88.21 & 86.69 & 149 & $\begin{array}{l}\text { Nech Tilik } \\
\text { Shenkora }\end{array}$ & 100 & 34.56 & -7.60 & 79.42 \\
\hline 191 & $\begin{array}{c}\text { Kay } \\
\text { Shenkora }\end{array}$ & 131 & 87.81 & -2.24 & 92.65 & 138 & $\begin{array}{l}\text { Kay } \\
\text { Ageda }\end{array}$ & 115 & 73.31 & 87.40 & 85.89 & 16 & $\begin{array}{l}\text { Wolesh/ } \\
\text { Tinkish }\end{array}$ & 99 & 32.55 & -8.99 & 76.73 \\
\hline 188 & Aladi & 131 & 87.46 & -2.43 & 92.28 & 372 & CO-602 & 112 & 68.05 & 81.71 & 80.24 & 313 & CO 1230 & 98 & 31.88 & -9.45 & 75.84 \\
\hline 160 & $\begin{array}{l}\text { Shenkora } \\
\text { Adi }\end{array}$ & 130 & 86.02 & -3.17 & 90.81 & 427 & NCD 376 & 112 & 67.67 & 81.30 & 79.84 & 289 & CO 798 & 97 & 30.54 & -10.37 & 74.05 \\
\hline 29 & $\begin{array}{c}\text { Andegna } \\
\text { dereja } \\
\text { Wonji }\end{array}$ & 129 & 84.59 & -3.92 & 89.34 & 1 & $\begin{array}{c}\text { Nech } \\
\text { Shenkora }\end{array}$ & 111 & 66.17 & 79.67 & 78.23 & 290 & CO 810 & 97 & 29.87 & -10.83 & 73.15 \\
\hline 311 & CO 1202 & 129 & 84.59 & -3.92 & 89.34 & 40 & $\begin{array}{l}\text { Atena } \\
\text { Moris }\end{array}$ & 111 & 66.17 & 79.67 & 78.23 & 328 & H48/4605 & 96 & 28.52 & -11.75 & 71.36 \\
\hline 224 & В 52298 & 70 & 0.00 & -47.95 & 2.57 & 224 & B 52298 & 67 & 0.00 & 8.13 & 7.26 & 224 & В 52298 & 75 & 0.00 & -31.34 & 33.33 \\
\hline \multirow[t]{2}{*}{424} & NCO 334 & 134 & 92.11 & 0.00 & 97.06 & 424 & NCO 334 & 62 & -7.52 & 0.00 & -0.81 & 424 & NCO 334 & 109 & 45.64 & 0.00 & 94.18 \\
\hline & $\mathrm{MCV}$ & 68 & -2.51 & -49.25 & 0.00 & & $\mathrm{MCV}$ & 62 & -6.77 & 0.81 & 0.00 & & MCV & 56 & -25.00 & -48.50 & 0.00 \\
\hline
\end{tabular}




\section{Continued}

\begin{tabular}{|c|c|c|c|c|c|c|c|c|c|c|c|c|c|c|c|c|c|}
\hline \multirow[t]{2}{*}{ Code } & \multirow[t]{2}{*}{ Acssessions } & \multirow[t]{2}{*}{ Mean } & \multicolumn{3}{|c|}{$\begin{array}{l}\text { Comparative } \\
\text { advantage } \\
\text { (\% over) }\end{array}$} & \multirow[t]{2}{*}{ Code } & \multirow[t]{2}{*}{ Accessions } & \multirow[t]{2}{*}{ Mean } & \multicolumn{3}{|c|}{$\begin{array}{c}\text { Comparative } \\
\text { advantage } \\
\text { ( } \% \text { over) }\end{array}$} & \multirow[t]{2}{*}{ Code } & \multirow[t]{2}{*}{ Acssessions } & \multirow[t]{2}{*}{ Mean } & \multicolumn{3}{|c|}{$\begin{array}{c}\text { Comparative } \\
\text { advantage } \\
\text { (\% over) }\end{array}$} \\
\hline & & & $\begin{array}{c}\text { B } \\
52298\end{array}$ & $\begin{array}{c}\text { NCO } \\
334\end{array}$ & $\mathrm{MCV}$ & & & & $\begin{array}{c}\text { B } \\
52298\end{array}$ & $\begin{array}{c}\text { NCO } \\
334\end{array}$ & MCV & & & & $\begin{array}{c}\text { B } \\
52298\end{array}$ & $\begin{array}{c}\text { NCO } \\
334\end{array}$ & MCV \\
\hline \multicolumn{2}{|c|}{ MSCPL } & & & & & \multicolumn{2}{|r|}{ CYPL } & \multicolumn{10}{|c|}{ SCW } \\
\hline 203 & В 4425 & 164 & 84.23 & 35.68 & 131.59 & 151 & $\begin{array}{l}\text { Nech } \\
\text { Ageda }\end{array}$ & 244.89 & 55.72 & 39.32 & 123.99 & 273 & CO 475 & 2.96 & 66.71 & 104.50 & 96.54 \\
\hline 205 & В 45154 & 140 & 58.03 & 16.39 & 98.65 & 140 & $\begin{array}{l}\text { Kay } \\
\text { Ageda }\end{array}$ & 242.08 & 53.93 & 37.72 & 121.42 & 75 & Shenkora & 2.68 & 51.34 & 85.64 & 78.42 \\
\hline 291 & CO 842 & 140 & 58.03 & 16.39 & 98.65 & 43 & Moris & 236.49 & 50.38 & 34.54 & 116.31 & 20 & Wonji & 2.64 & 48.94 & 82.70 & 75.59 \\
\hline 210 & В 4906 & 139 & 56.06 & 14.94 & 96.18 & 4 & $\begin{array}{l}\text { Andegna } \\
\text { Dereja } \\
\text { Canada } \\
\text { Shenkora }\end{array}$ & 228.24 & 45.13 & 29.85 & 108.76 & 87 & $\begin{array}{l}\text { Dalecha } \\
\text { Shenkora }\end{array}$ & 2.53 & 42.60 & 74.91 & 68.11 \\
\hline 296 & CO 957 & 137 & 54.65 & 13.90 & 94.41 & 139 & $\begin{array}{c}\text { Kay } \\
\text { Shenkora }\end{array}$ & 225.93 & 43.66 & 28.53 & 106.65 & 38 & $\begin{array}{c}\text { Kay } \\
\text { Shenkora }\end{array}$ & 2.50 & 41.04 & 73.01 & 66.28 \\
\hline 153 & $\begin{array}{l}\text { Ye Beskula } \\
\text { Shenkora }\end{array}$ & 135 & 51.83 & 11.83 & 90.86 & 153 & $\begin{array}{c}\text { Ye } \\
\text { Beskula } \\
\text { Shenkora }\end{array}$ & 213.45 & 35.73 & 21.43 & 95.23 & 4 & $\begin{array}{l}\text { Andegna } \\
\text { Dereja } \\
\text { Canada } \\
\text { Shenkora }\end{array}$ & 2.50 & 40.90 & 72.84 & 66.11 \\
\hline 151 & $\begin{array}{l}\text { Nech } \\
\text { Ageda }\end{array}$ & 134 & 50.70 & 11.00 & 89.45 & 60 & Moris & 211.75 & 34.65 & 20.47 & 93.68 & 177 & Holland & 2.30 & 29.90 & 59.34 & 53.14 \\
\hline 188 & Aladi & 129 & 45.07 & 6.85 & 82.37 & 46 & Wotete & 211.20 & 34.30 & 20.15 & 93.18 & 82 & $\begin{array}{l}\text { Tikur } \\
\text { Ageda }\end{array}$ & 2.28 & 28.77 & 57.96 & 51.81 \\
\hline 43 & Moris & 124 & 39.15 & 2.49 & 74.93 & 177 & Holland & 207.68 & 32.06 & 18.15 & 89.95 & 24 & $\begin{array}{c}\text { Nech } \\
\text { Sidancho }\end{array}$ & 2.28 & 28.35 & 57.44 & 51.31 \\
\hline 424 & NCO 334 & 121 & 35.77 & 0.00 & 70.68 & 203 & B 4425 & 206.00 & 30.99 & 17.20 & 88.42 & 227 & B 53164 & 2.25 & 27.08 & 55.88 & 49.82 \\
\hline 220 & B 51410 & 118 & 32.68 & -2.28 & 66.78 & 190 & Engda & 201.00 & 27.81 & 14.35 & 83.85 & 176 & Shekole & 2.19 & 23.27 & 51.21 & 45.33 \\
\hline 328 & H48/4605 & 116 & 30.14 & -4.15 & 63.60 & 138 & $\begin{array}{c}\text { Kay } \\
\text { Ageda }\end{array}$ & 197.88 & 25.82 & 12.57 & 80.99 & 89 & $\begin{array}{c}\text { Kay } \\
\text { Shenkora } \\
\text { Ageda }\end{array}$ & 2.17 & 22.28 & 50.00 & 44.16 \\
\hline 60 & Moris & 115 & 29.30 & -4.77 & 62.54 & 157 & $\begin{array}{c}\text { Kay } \\
\text { Ageda/ } \\
\text { Shenkora }\end{array}$ & 197.80 & 25.78 & 12.53 & 80.92 & 441 & B80-505 & 2.16 & 22.00 & 49.65 & 43.83 \\
\hline 139 & $\begin{array}{c}\text { Kay } \\
\text { Shenkora }\end{array}$ & 112 & 25.63 & -7.47 & 57.93 & 189 & Erero & 195.58 & 24.36 & 11.26 & 78.89 & 81 & $\begin{array}{l}\text { Kay } \\
\text { Ageda }\end{array}$ & 2.16 & 21.58 & 49.13 & 43.33 \\
\hline 187 & $\begin{array}{c}\text { Shenkora } \\
\text { Adi }\end{array}$ & 112 & 25.63 & -7.47 & 57.93 & 159 & $\begin{array}{c}\text { Nech } \\
\text { Shenkora }\end{array}$ & 194.85 & 23.90 & 10.85 & 78.22 & 12 & $\begin{array}{l}\text { Yejima } \\
\text { Shenkora }\end{array}$ & 2.14 & 20.87 & 48.27 & 42.50 \\
\hline 140 & $\begin{array}{c}\text { Kay } \\
\text { Ageda }\end{array}$ & 111 & 25.35 & -7.68 & 57.58 & 422 & N 55/805 & 193.54 & 23.07 & 10.11 & 77.02 & 140 & $\begin{array}{c}\text { Kay } \\
\text { Ageda }\end{array}$ & 2.12 & 19.32 & 46.37 & 40.67 \\
\hline 348 & CP72/2083 & 111 & 24.79 & -8.09 & 56.87 & 164 & $\begin{array}{l}\text { Yemilat } \\
\text { Nech } \\
\text { Shenkora }\end{array}$ & 191.81 & 21.97 & 9.12 & 75.44 & 189 & Erero & 2.11 & 18.90 & 45.85 & 40.17 \\
\hline 395 & B80-250 & 111 & 24.79 & -8.09 & 56.87 & 141 & $\begin{array}{c}\text { Nech } \\
\text { Shenkora }\end{array}$ & 191.80 & 21.96 & 9.12 & 75.43 & 71 & $\begin{array}{c}\text { Bicha } \\
\text { Shenkora }\end{array}$ & 2.09 & 17.91 & 44.64 & 39.01 \\
\hline 242 & В 60267 & 109 & 22.82 & -9.54 & 54.39 & 142 & $\begin{array}{c}\text { Kay } \\
\text { Ageda }\end{array}$ & 183.38 & 16.60 & 4.32 & 67.73 & 190 & Engda & 2.08 & 17.49 & 44.12 & 38.51 \\
\hline 224 & В 52298 & 89 & 0.00 & -26.35 & 25.71 & 224 & В 52298 & 157.26 & 0.00 & -10.53 & 43.84 & 224 & В 52298 & 1.77 & 0.00 & 22.66 & 17.89 \\
\hline \multirow[t]{2}{*}{424} & NCO 334 & 121 & 35.77 & 0.00 & 70.68 & 424 & NCO 334 & 175.78 & 11.77 & 0.00 & 60.77 & 424 & NCO 334 & 1.46 & -17.91 & 0.00 & -3.23 \\
\hline & MCV & 71 & -20.45 & -41.41 & 0.00 & & MCV & 109.33 & -30.48 & -37.80 & 0.00 & & MCV & 1.50 & -15.18 & 4.05 & 0.00 \\
\hline
\end{tabular}




\section{Continued}

\begin{tabular}{|c|c|c|c|c|c|c|c|c|c|c|c|c|c|c|c|c|c|}
\hline \multirow[t]{2}{*}{ Code } & \multirow[t]{2}{*}{ Acssessions } & \multirow[t]{2}{*}{ Mean } & \multicolumn{3}{|c|}{$\begin{array}{l}\text { Comparative } \\
\text { advantage } \\
\text { (\% over) }\end{array}$} & \multirow[t]{2}{*}{ Code } & \multirow[t]{2}{*}{ Accessions } & \multirow[t]{2}{*}{ Mean } & \multicolumn{3}{|c|}{$\begin{array}{l}\text { Comparative } \\
\text { advantage } \\
\text { (\% over) }\end{array}$} & \multirow[t]{2}{*}{ Code } & \multirow[t]{2}{*}{ Acssessions } & \multirow[t]{2}{*}{ Mean } & \multicolumn{3}{|c|}{$\begin{array}{l}\text { Comparative } \\
\text { advantage } \\
\text { (\% over) }\end{array}$} \\
\hline & & & $\begin{array}{c}\text { B } \\
52298\end{array}$ & $\begin{array}{c}\text { NCO } \\
334\end{array}$ & MCV & & & & $\begin{array}{c}\text { B } \\
52298\end{array}$ & $\begin{array}{c}\text { NCO } \\
334\end{array}$ & $\mathrm{MCV}$ & & & & $\begin{array}{c}\text { B } \\
52298\end{array}$ & $\begin{array}{c}\text { NCO } \\
334\end{array}$ & MCV \\
\hline & NOI & & & & & & SH & & & & & & SD & & & & \\
\hline 167 & $\begin{array}{c}\text { Kay } \\
\text { Shenkora }\end{array}$ & 41 & 56.73 & 53.77 & 52.48 & 318 & СР 29/320 & 299.10 & 51.71 & 24.75 & 27.91 & 10 & $\begin{array}{l}\text { Burabure } \\
\text { Shenkora }\end{array}$ & 3.32 & 20.60 & 17.61 & 25.45 \\
\hline 66 & $\begin{array}{l}\text { Nech } \\
\text { Ageda }\end{array}$ & 39 & 50.96 & 48.11 & 46.87 & 207 & B 47386 & 297.53 & 50.91 & 24.10 & 27.24 & 20 & Wonji & 3.29 & 19.42 & 16.46 & 24.22 \\
\hline 61 & $\begin{array}{c}\text { Kay } \\
\text { Shenkora }\end{array}$ & 39 & 49.04 & 46.23 & 45.00 & 77 & $\begin{array}{l}\text { Ye Kenya } \\
\text { Ageda }\end{array}$ & 297.28 & 50.79 & 23.99 & 27.13 & 99 & Shilmu & 3.27 & 18.51 & 15.58 & 23.28 \\
\hline 145 & $\begin{array}{c}\text { Kay } \\
\text { Shenkora } \\
\text { (Burabure) }\end{array}$ & 39 & 48.08 & 45.28 & 44.06 & 309 & CO 1190 & 296.53 & 50.41 & 23.68 & 26.81 & 114 & $\begin{array}{l}\text { Ye Bure } \\
\text { Shenkora }\end{array}$ & 3.27 & 18.51 & 15.58 & 23.28 \\
\hline 111 & $\begin{array}{c}\text { Tikur } \\
\text { Shenkora }\end{array}$ & 38 & 47.12 & 44.34 & 43.12 & 334 & СР 60/23 & 294.50 & 49.38 & 22.84 & 25.94 & 82 & $\begin{array}{l}\text { Tikur } \\
\text { Ageda }\end{array}$ & 3.26 & 18.42 & 15.49 & 23.18 \\
\hline 144 & $\begin{array}{l}\text { Kay Ageda/ } \\
\text { Shenkora }\end{array}$ & 38 & 46.15 & 43.40 & 42.19 & 373 & Н 38/4443 & 292.76 & 48.50 & 22.11 & 25.20 & 175 & Wonji/Bula/ & 3.26 & 18.42 & 15.49 & 23.18 \\
\hline 210 & В 4906 & 38 & 46.15 & 43.40 & 42.19 & 317 & CP 29/291 & 290.88 & 47.54 & 21.32 & 24.39 & 4 & $\begin{array}{l}\text { Andegna } \\
\text { Dereja } \\
\text { Canada } \\
\text { Shenkora }\end{array}$ & 3.26 & 18.24 & 15.31 & 22.99 \\
\hline 162 & $\begin{array}{l}\text { Shenkora } \\
\text { Dima }\end{array}$ & 37 & 42.31 & 39.62 & 38.45 & 149 & $\begin{array}{l}\text { Nech Tilik } \\
\text { Shenkora }\end{array}$ & 290.43 & 47.31 & 21.14 & 24.20 & 123 & $\begin{array}{c}\text { Kay } \\
\text { Shenkora }\end{array}$ & 3.23 & 17.06 & 14.16 & 21.77 \\
\hline 65 & $\begin{array}{l}\text { Tikur } \\
\text { Ageda }\end{array}$ & 37 & 40.38 & 37.74 & 36.58 & 39 & $\begin{array}{c}\text { Kay } \\
\text { Shenkora }\end{array}$ & 290.19 & 47.19 & 21.04 & 24.10 & 215 & B 51116 & 3.23 & 17.06 & 14.16 & 21.77 \\
\hline 104 & $\begin{array}{l}\text { Burabure } \\
\text { Shenkora }\end{array}$ & 37 & 40.38 & 37.74 & 36.58 & 38 & $\begin{array}{c}\text { Kay } \\
\text { Shenkora }\end{array}$ & 288.79 & 46.48 & 20.45 & 23.50 & 164 & $\begin{array}{l}\text { Yemilat } \\
\text { Nech } \\
\text { Shenkora }\end{array}$ & 3.22 & 16.97 & 14.07 & 21.67 \\
\hline 19 & $\begin{array}{l}\text { Burabure } \\
\text { Shenkora }\end{array}$ & 36 & 38.46 & 35.85 & 34.71 & 103 & $\begin{array}{c}\text { Nech } \\
\text { Shenkora }\end{array}$ & 288.48 & 46.32 & 20.32 & 23.37 & 24 & $\begin{array}{c}\text { Nech } \\
\text { Sidancho }\end{array}$ & 3.22 & 16.79 & 13.89 & 21.48 \\
\hline 76 & $\begin{array}{l}\text { Tikur } \\
\text { Ageda }\end{array}$ & 36 & 38.46 & 35.85 & 34.71 & 296 & CO 957 & 288.38 & 46.27 & 20.28 & 23.32 & 115 & $\begin{array}{l}\text { Nech } \\
\text { Ageda }\end{array}$ & 3.21 & 16.33 & 13.45 & 21.01 \\
\hline 57 & $\begin{array}{l}\text { Shenkora } \\
\text { Dima/Kay } \\
\text { Shenkora }\end{array}$ & 36 & 36.54 & 33.96 & 32.83 & 378 & Н 44/3098 & 287.84 & 46.00 & 20.06 & 23.09 & 250 & BO 3 & 3.20 & 16.24 & 13.36 & 20.92 \\
\hline 441 & B80-505 & 36 & 36.54 & 33.96 & 32.83 & 92 & $\begin{array}{l}\text { Ye Bako } \\
\text { Shenkora }\end{array}$ & 286.35 & 45.24 & 19.44 & 22.46 & 157 & $\begin{array}{l}\text { Kay Ageda/ } \\
\text { Shenkora }\end{array}$ & 3.20 & 16.15 & 13.27 & 20.82 \\
\hline 45 & Abesha & 35 & 35.58 & 33.02 & 31.90 & 177 & Holland & 286.33 & 45.23 & 19.43 & 22.45 & 227 & В 53164 & 3.15 & 14.34 & 11.50 & 18.94 \\
\hline 172 & $\begin{array}{c}\text { Nech } \\
\text { Shenkora }\end{array}$ & 35 & 34.62 & 32.08 & 30.96 & 20 & Wonji & 285.60 & 44.86 & 19.12 & 22.14 & 38 & $\begin{array}{c}\text { Kay } \\
\text { Shenkora }\end{array}$ & 3.14 & 13.79 & 10.97 & 18.37 \\
\hline 178 & Bure & 35 & 34.62 & 32.08 & 30.96 & 270 & CO 453 & 284.98 & 44.55 & 18.86 & 21.87 & 39 & $\begin{array}{c}\text { Kay } \\
\text { Shenkora }\end{array}$ & 3.14 & 13.79 & 10.97 & 18.37 \\
\hline 185 & Bure & 35 & 34.62 & 32.08 & 30.96 & 193 & B35269 & 284.78 & 44.45 & 18.78 & 21.79 & 234 & В 5736 & 3.14 & 13.79 & 10.97 & 18.37 \\
\hline 166 & $\begin{array}{l}\text { Burabure } \\
\text { Shenkora }\end{array}$ & 35 & 33.65 & 31.13 & 30.03 & 43 & Moris & 283.13 & 43.61 & 18.09 & 21.08 & 136 & $\begin{array}{c}\text { Bicha } \\
\text { Shenkora }\end{array}$ & 3.13 & 13.70 & 10.88 & 18.27 \\
\hline 224 & В 52298 & 26 & 0.00 & -1.89 & -2.71 & 224 & В 52298 & 197.15 & 0.00 & -17.77 & -15.69 & 224 & В 52298 & 2.755 & 0.00 & -2.48 & 4.02 \\
\hline \multirow[t]{2}{*}{424} & NCO 334 & 27 & 1.92 & 0.00 & -0.84 & 424 & NCO 334 & 239.75 & 21.61 & 0.00 & 2.53 & 424 & NCO 334 & 2.825 & 2.54 & 0.00 & 6.66 \\
\hline & MCV & 27 & 2.79 & 0.85 & 0.00 & & MCV & 233.83 & 18.61 & -2.47 & 0.00 & & MCV & 2.6485 & -3.87 & -6.25 & 0.00 \\
\hline
\end{tabular}




\begin{tabular}{|c|c|c|c|c|c|c|c|c|c|c|c|c|c|c|c|c|c|}
\hline \multirow[t]{2}{*}{ Code } & \multirow[t]{2}{*}{ Acssessions } & \multirow[t]{2}{*}{ Mean } & \multicolumn{3}{|c|}{$\begin{array}{l}\text { Comparative } \\
\text { advantage } \\
\text { (\% over) }\end{array}$} & \multirow[t]{2}{*}{ Code } & \multirow[t]{2}{*}{ Accessions } & \multirow[t]{2}{*}{ Mean } & \multicolumn{3}{|c|}{$\begin{array}{l}\text { Comparative } \\
\text { advantage } \\
\text { (\% over) }\end{array}$} & \multirow[t]{2}{*}{ Code } & \multirow[t]{2}{*}{ Acssessions } & \multirow[t]{2}{*}{ Mean } & \multicolumn{3}{|c|}{$\begin{array}{c}\text { Comparative advantage } \\
\text { (\% over) }\end{array}$} \\
\hline & & & $\begin{array}{c}\text { B } \\
52298\end{array}$ & $\begin{array}{l}\text { NCO } \\
334\end{array}$ & MCV & & & & $\begin{array}{c}\text { B } \\
52298\end{array}$ & $\begin{array}{c}\text { NCO } \\
334\end{array}$ & MCV & & & & $\begin{array}{c}\text { B } \\
52298\end{array}$ & $\begin{array}{c}\text { NCO } \\
334\end{array}$ & MCV \\
\hline 424 & NCO 334 & 665.12 & 41.43 & 0.00 & 44.03 & 151 & $\begin{array}{l}\text { Nech } \\
\text { Ageda }\end{array}$ & 465.50 & 60.66 & 38.13 & 127.85 & 129 & $\begin{array}{c}\text { Nech } \\
\text { Shenkora }\end{array}$ & 22.12 & 9.32 & 10.81 & 12.99 \\
\hline 77 & $\begin{array}{l}\text { Ye Kenya } \\
\text { Ageda }\end{array}$ & 645.29 & 37.21 & -2.98 & 39.73 & 43 & Moris & 439.75 & 51.77 & 30.49 & 115.25 & 281 & CO 684 & 21.72 & 7.33 & 8.79 & 10.94 \\
\hline 35 & $\begin{array}{c}\text { Nech } \\
\text { Shenkora }\end{array}$ & 629.70 & 33.90 & -5.33 & 36.35 & 140 & $\begin{array}{l}\text { Kay } \\
\text { Ageda }\end{array}$ & 433.00 & 49.44 & 28.49 & 111.94 & 410 & $\begin{array}{l}\text { Yellow } \\
\text { Cane }\end{array}$ & 21.56 & 6.56 & 8.02 & 10.14 \\
\hline 28 & $\begin{array}{c}\text { Nech } \\
\text { Shenkora }\end{array}$ & 600.90 & 27.77 & -9.66 & 30.12 & 4 & $\begin{array}{l}\text { Andegna } \\
\text { Dereja } \\
\text { Canada } \\
\text { Shenkora }\end{array}$ & 395.25 & 36.41 & 17.28 & 93.46 & 427 & NCD 376 & 21.43 & 5.93 & 7.38 & 9.49 \\
\hline 437 & Pindar & 579.87 & 23.30 & -12.82 & 25.57 & 203 & B 4425 & 391.25 & 35.03 & 16.10 & 91.51 & 390 & Mex 52/29 & 21.34 & 5.47 & 6.91 & 9.02 \\
\hline 4 & $\begin{array}{l}\text { Andegna } \\
\text { Dereja } \\
\text { Canada } \\
\text { Shenkora }\end{array}$ & 579.63 & 23.25 & -12.85 & 25.51 & 190 & Engda & 389.50 & 34.43 & 15.58 & 90.65 & 233 & В $80-250$ & 21.33 & 5.41 & 6.85 & 8.96 \\
\hline 71 & $\begin{array}{c}\text { Bicha } \\
\text { Shenkora }\end{array}$ & 572.98 & 21.84 & -13.85 & 24.07 & 422 & N 55/805 & 387.25 & 33.65 & 14.91 & 89.55 & 235 & В 5780 & 21.25 & 5.02 & 6.45 & 8.55 \\
\hline 231 & В 57133 & 557.19 & 18.48 & -16.23 & 20.65 & 60 & Moris & 386.25 & 33.30 & 14.61 & 89.06 & 216 & В 51129 & 21.22 & 4.87 & 6.30 & 8.39 \\
\hline 149 & $\begin{array}{c}\text { Nech } \\
\text { Tilik } \\
\text { Shenkora }\end{array}$ & 555.68 & 18.16 & -16.45 & 20.33 & 46 & Wotete & 372.50 & 28.56 & 10.53 & 82.33 & 225 & B 52313 & 21.19 & 4.72 & 6.15 & 8.24 \\
\hline 31 & $\begin{array}{l}\text { Huletegna } \\
\text { dereja } \\
\text { Jambo } \\
\text { Kay }\end{array}$ & 554.93 & 18.00 & -16.57 & 20.16 & 177 & Holland & 371.50 & 28.21 & 10.24 & 81.84 & 356 & D $141 / 46$ & 21.13 & 4.42 & 5.85 & 7.93 \\
\hline 2 & $\begin{array}{l}\text { Bicha } \\
\text { Shenkora/ } \\
\text { Weliso }\end{array}$ & 553.05 & 17.60 & -16.85 & 19.76 & 153 & $\begin{array}{c}\text { Ye } \\
\text { Beskula } \\
\text { Shenkora }\end{array}$ & 369.00 & 27.35 & 9.50 & 80.61 & 391 & $\begin{array}{c}\text { Mex } \\
53 / 142\end{array}$ & 21.12 & 4.37 & 5.80 & 7.88 \\
\hline 140 & $\begin{array}{l}\text { Kay } \\
\text { Ageda }\end{array}$ & 548.47 & 16.62 & -17.54 & 18.77 & 164 & $\begin{array}{l}\text { Yemilat } \\
\text { Nech } \\
\text { Shenkora }\end{array}$ & 366.75 & 26.57 & 8.83 & 79.51 & 260 & C $105-73$ & 21.11 & 4.35 & 5.77 & 7.86 \\
\hline 227 & В 53164 & 543.89 & 15.65 & -18.23 & 17.77 & 189 & Erero & 366.25 & 26.40 & 8.68 & 79.27 & 389 & M 377/5 & 21.08 & 4.18 & 5.60 & 7.68 \\
\hline 124 & $\begin{array}{c}\text { Kay } \\
\text { Shenkora }\end{array}$ & 543.24 & 15.51 & -18.32 & 17.63 & 138 & $\begin{array}{l}\text { Kay } \\
\text { Ageda }\end{array}$ & 358.50 & 23.73 & 6.38 & 75.48 & 334 & СР 60/23 & 21.08 & 4.16 & 5.59 & 7.67 \\
\hline 364 & Ebene 1/37 & 541.54 & 15.15 & -18.58 & 17.26 & 7 & $\begin{array}{c}\text { Kay } \\
\text { Sidancho }\end{array}$ & 352.00 & 21.48 & 4.45 & 72.29 & 229 & В 54142 & 21.06 & 4.08 & 5.50 & 7.58 \\
\hline 334 & СР 60/23 & 538.82 & 14.57 & -18.99 & 16.68 & 159 & $\begin{array}{l}\text { Nech } \\
\text { Shenkora }\end{array}$ & 350.75 & 21.05 & 4.08 & 71.68 & 244 & B 6113 & 21.06 & 4.08 & 5.50 & 7.58 \\
\hline 255 & СВ 40-35 & 538.52 & 14.51 & -19.03 & 16.61 & 141 & $\begin{array}{l}\text { Nech } \\
\text { Shenkora }\end{array}$ & 347.25 & 19.84 & 3.04 & 69.97 & 22 & American & 21.03 & 3.95 & 5.37 & 7.45 \\
\hline 385 & M 53/263 & 535.97 & 13.97 & -19.42 & 16.06 & 157 & $\begin{array}{c}\text { Kay } \\
\text { Ageda/ } \\
\text { Shenkora }\end{array}$ & 345.75 & 19.33 & 2.60 & 69.23 & 331 & M442/51 & 20.96 & 3.61 & 5.02 & 7.09 \\
\hline 34 & Moliso & 535.11 & 13.78 & -19.55 & 15.87 & 188 & Aladi & 345.00 & 19.07 & 2.37 & 68.87 & 187 & $\begin{array}{l}\text { Shenkora } \\
\text { Adi }\end{array}$ & 20.92 & 3.41 & 4.82 & 6.89 \\
\hline 224 & B 52298 & 470.29 & 0.00 & -29.29 & 1.84 & 224 & В 52298 & 289.75 & 0.00 & -14.02 & 41.82 & 224 & В 52298 & 20.23 & 0.00 & 1.37 & 3.36 \\
\hline 424 & NCO 334 & 665.12 & 41.43 & 0.00 & 44.03 & 424 & NCO 334 & 337.00 & 16.31 & 0.00 & 64.95 & 424 & NCO 334 & 19.96 & -1.35 & 0.00 & 1.97 \\
\hline & MCV & 461.81 & -1.80 & -30.57 & 0.00 & & $\mathrm{MCV}$ & 204.30 & -29.49 & -39.38 & 0.00 & & MCV & 19.57 & -3.25 & -1.93 & 0.00 \\
\hline
\end{tabular}




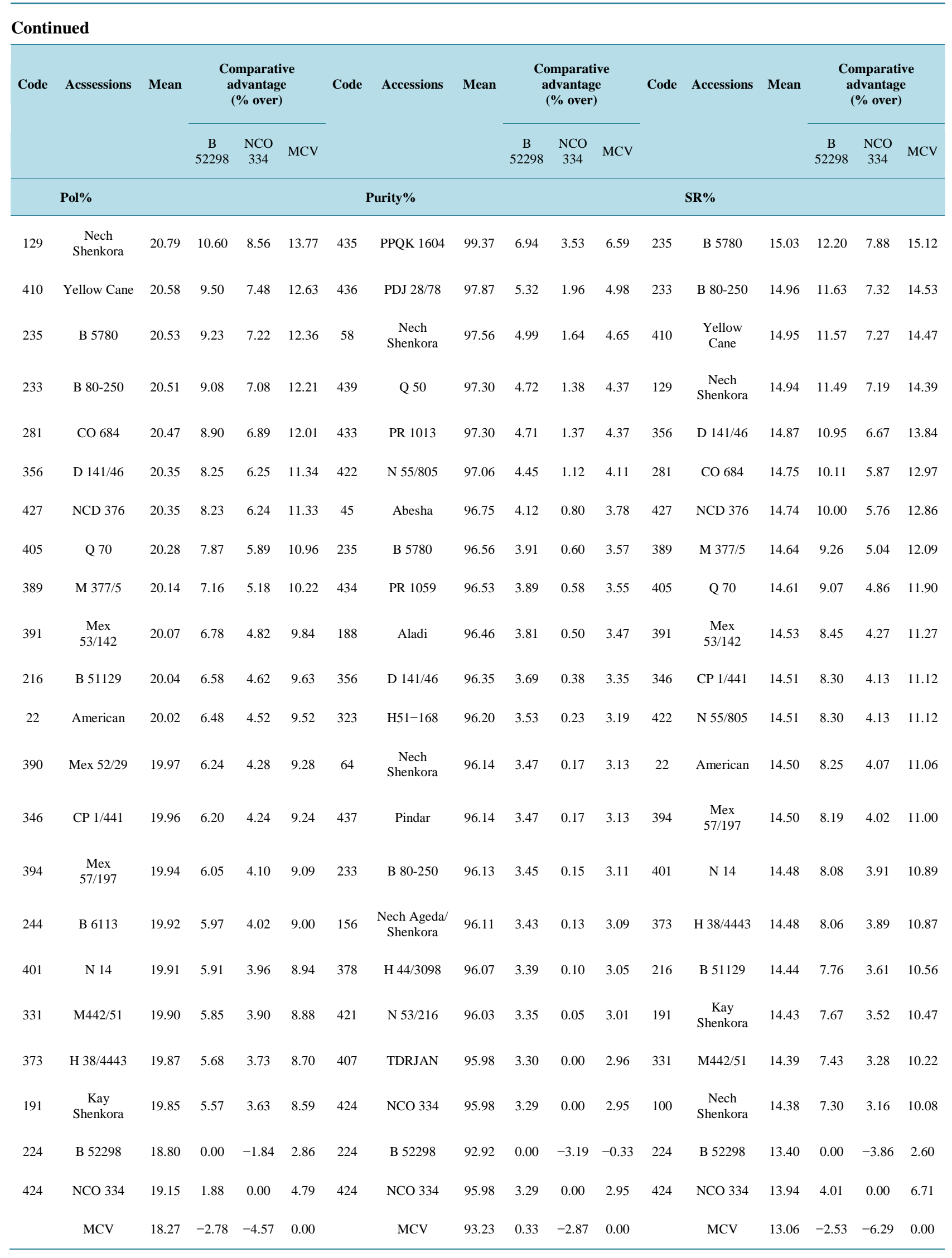




\section{Continued}

\begin{tabular}{|c|c|c|c|c|c|}
\hline \multirow[t]{2}{*}{ Code } & \multirow{2}{*}{$\begin{array}{c}\text { Acssessions } \\
\text { HRBrix10MAP }\end{array}$} & \multirow[t]{2}{*}{ Mean } & \multicolumn{3}{|c|}{ Comparative advantage (\% over) } \\
\hline & & & В 52298 & NCO 334 & MCV \\
\hline 381 & L 60-25 & 17.61 & 13.99 & 30.31 & 13.76 \\
\hline 239 & B 59250 & 17.41 & 12.74 & 28.89 & 12.52 \\
\hline 241 & B 60163 & 17.31 & 12.08 & 28.13 & 11.86 \\
\hline 66 & Nech Ageda & 17.28 & 11.88 & 27.91 & 11.66 \\
\hline 401 & N 14 & 17.26 & 11.74 & 27.74 & 11.52 \\
\hline 59 & Nech Shenkora & 17.19 & 11.31 & 27.26 & 11.10 \\
\hline 55 & Kay Shenkora & 17.17 & 11.15 & 27.07 & 10.94 \\
\hline 173 & Misrah & 17.14 & 10.94 & 26.83 & 10.73 \\
\hline 61 & Kay Shenkora & 17.07 & 10.52 & 26.35 & 10.31 \\
\hline 419 & N 51/539 & 17.06 & 10.47 & 26.30 & 10.26 \\
\hline 432 & PR 1007 & 16.93 & 9.61 & 25.31 & 9.40 \\
\hline 345 & СР 71/421 & 16.92 & 9.57 & 25.26 & 9.35 \\
\hline 218 & B 51132 & 16.92 & 9.55 & 25.24 & 9.34 \\
\hline 348 & CP72/2083 & 16.92 & 9.53 & 25.22 & 9.32 \\
\hline 152 & Nech Tinish Shenkora & 16.85 & 9.08 & 24.70 & 8.87 \\
\hline 160 & Shenkora Adi & 16.76 & 8.50 & 24.04 & 8.29 \\
\hline 233 & В $80-250$ & 16.75 & 8.43 & 23.96 & 8.22 \\
\hline 181 & Gende Lega & 16.74 & 8.37 & 23.89 & 8.16 \\
\hline 126 & Nech Shenkora & 16.73 & 8.34 & 23.85 & 8.13 \\
\hline 237 & B 59104 & 16.73 & 8.34 & 23.85 & 8.13 \\
\hline 224 & В 52298 & 15.45 & 0.00 & 14.32 & -0.19 \\
\hline \multirow[t]{2}{*}{424} & NCO 334 & 13.51 & -12.53 & 0.00 & -12.70 \\
\hline & $\mathrm{MCV}$ & 15.48 & 0.19 & 14.54 & 0.00 \\
\hline
\end{tabular}

TC4MAP and TC5MAP = Tiller counts 4 and 5 month after planting; STC10MAP = Stalk count 10 months after planting; HRBrix10MAP = Hand rifractometer brix reading 10 months after planting; MSCPL = Millable stalk count per plot; SCW = Single cane weight (Kg); NOI = Number of internode; IL = Internode length $(\mathrm{cm}) ; \mathrm{SH}=$ Stalk height $(\mathrm{cm}) ; \mathrm{SD}=$ Stalk diameter $(\mathrm{cm}) ; \mathrm{LA}=$ Leaf area $\left(\mathrm{cm}^{2} ; \mathrm{CYPL}=\right.$ Cane yield per plot $(\mathrm{Kg}) ;$ Brix\% $=$ Brix percent; Pol\% = Pol percent; Purity\% = Purity percent; SR\% = Sugar percent; SY = Sugar yield (qt/ha); MCV = Mean of commercial varieties. 